\title{
Financial reporting in hyperinflationary economies and the value relevance of accounting amounts: Hard evidence from Zimbabwe
}

\author{
Eddie Chamisa* \\ Department of Finance and Tax, University of Cape Town, Cape Town, South Africa. \\ Musa Mangena \\ Accounting Group, Essex Business School, University of Essex, Colchester, UK. \\ Hamutyinei Harvey Pamburai \\ Department of Finance and Tax, University of Cape Town, Cape Town, South Africa. \\ Venancio Tauringana \\ University of Southampton, Southampton Business School, Centre for Research in \\ Accounting, Accountability and Governance, Southampton, UK.
}

\begin{abstract}
We examine the relative and incremental value relevance of inflation-adjusted (IA) and historical cost (HC) amounts in a hyperinflationary economy. Using an innovative setting and a unique dataset drawn from annual reports of firms listed on the Zimbabwe Stock Exchange for the 2000-2005 period, we find that both sets of amounts are value relevant, but HC amounts are superior to IA amounts. We also show that inflation gains and losses provide incremental information content beyond that provided by the $\mathrm{HC}$ amounts and that the power of this incremental content model is equivalent to that of the $\mathrm{HC}$ model but superior to that of the IA model. Furthermore, we find that during the period of relatively low inflation, HC amounts are more value relevant than IA amounts, but the differences are less discernible during the period of relatively high inflation. Our analyses further show that the value relevance of both IA and $\mathrm{HC}$ amounts increases with the inflation rate, but the increase is greater for IA amounts. Finally, we show that $\mathrm{HC}$ amounts have a greater ability to predict future cash flows than IA amounts, which suggests that the superiority of the value relevance of $\mathrm{HC}$ amounts relative to that of IA amounts stems from their ability to predict future cash flows. Overall, our results suggest that in periods of relatively low inflation, $\mathrm{HC}$ amounts are more value relevant, while in periods of relatively high inflation, the two sets of amounts are equally value relevant and provide incremental information beyond that provided by the other.
\end{abstract}

Keywords: IAS 29, historical cost amounts, inflation-adjusted amounts, value relevance, hyperinflationary economies.

JEL Classification: G15, M40, M41

*Corresponding author: Department of Finance and Tax, University of Cape Town, Private Bag, Rondebosch 7701, Cape Town, South Africa. E-mail: Edward.Chamisa@uct.ac.za. 


\section{Introduction}

In 1989, International Accounting Standard (IAS) 29 (Financial reporting in hyperinflationary economies) was issued and became effective for reporting periods beginning on or after 1 January 1990. The standard sets out the requirements for financial statements in a hyperinflationary environment. ${ }^{1}$ Fundamentally, the position of the standard is threefold (see IASB 2011: A938-39). First, it asserts that in a hyperinflationary economy, financial statements based on historical cost (HC) or current cost accounting are "not useful" and "are useful only if they are expressed in terms of the measuring unit current at the end of the reporting period". Second, it prohibits the presentation of inflation-adjusted (IA) financial statements as supplementary to HC financial statements. Finally, it discourages the separate presentation of HC financial statements. This position is underpinned by the recognition that inflation distorts accounting amounts under the $\mathrm{HC}$ accounting system. ${ }^{2}$

A conspicuous feature of the position taken by the standard on $\mathrm{HC}$ financial statements is the lack of underpinning conclusive evidence about the superiority of the value relevance of IA amounts over that of $\mathrm{HC}$ amounts. In the early 1980s, several studies examining the incremental value relevance of IA amounts demonstrated weak evidence, which led to the conclusion that IA data "are inconsequential for making financial decisions" (Konchitchki 2011: 1046). ${ }^{3}$ However, the most recent studies demonstrate that IA amounts have information content, but they do not support the superiority of IA over HC amounts. Konchitchki $(2011 ; 2013)$ shows that IA data have incremental information content for predicting future cash flows and stock valuation. In other studies, both HC and IA amounts are shown to have valuation implications, but the findings differ with regard to which set has greater value relevance. For example, Kirkulak and Balsari (2009) and Filip and Raffournier (2010) show that HC amounts are more value relevant, while Rivera (1987) and Barniv (1999) conclude that IA amounts have greater value relevance. Thus, the extent to which IA accounting amounts are superior to HC amounts remains an open empirical question.

\footnotetext{
1 IAS 29 states that an economy is hyperinflationary if (inter alia) "the cumulative inflation rate over three years is approaching, or exceeds, 100\%" (IASB 2011: A938).

2 The distortions arise primarily because the HC measurement system (a) violates the monetary unit assumption of a stable currency or constant purchasing power over time, (b) impairs comparability across firms and over time (given the mixing of dollars from different periods with different purchasing power), and (c) ignores inflation gains and losses such as gains that accumulate over time in nonmonetary assets (Konchitchki 2011; 2013).

3 These studies included, among many others, Beaver et al. (1980), Gheyara and Boatsman (1980), Beaver et al. (1983), Beaver and Landsman (1983), and Board and Walker (1984) (discussed in Section 3) and were a response to the 1970s and 1980s debate, particularly in the US and $\mathrm{UK}$, about the value of $\mathrm{HC}$ accounting amounts in periods of high inflation.
} 
In this study, we exploit Zimbabwe's unique dataset and innovative setting to provide new and hard evidence on the relative usefulness of accounting amounts obtained from accounting systems that focus on different measurement attributes. This issue is at the heart of the accounting profession in both practice and academia but has been overlooked. In particular, we examine the relative and incremental value relevance of HC and IA accounting amounts for stock valuation in a hyperinflationary environment. In addition, we examine the relative power of $\mathrm{HC}$ and IA accounting amounts in predicting future cash flows from operations. In this context, we provide insights into why the market may price the two sets of amounts differently. This issue has not yet been explored in studies on the value relevance of HC and IA amounts.

In 1999, Zimbabwe was designated a hyperinflationary economy by the regulatory authorities, namely, the Institute of Chartered Accountants of Zimbabwe (ICAZ) and the Zimbabwe Stock Exchange (ZSE). Consequently, effective for financial reporting periods beginning on or after 1 January 2000, listed and other large unlisted firms were required to restate their financial statements in accordance with IAS 29. However, contrary to the provisions of IAS 29 prohibiting the publication of HC statements in a hyperinflationary environment, the ICAZ and ZSE permitted firms to publish these statements as supplementary information. This was a compromise that was made after an agreement was reached with the IASB, following strong lobbying by preparers, auditors and users of financial statements in Zimbabwe against the adoption of IAS 29. In the end, firms voluntarily settled to present prominently both IA and $\mathrm{HC}$ amounts on the face of primary financial statements, side-by-side, ensuring that both sets of statements were audited and accompanied by detailed disclosure notes (see Appendix 1 for an example of the presentation format). To the firms, this provided the corner solution as it enabled them to be IAS 29 compliant and meet user demands for audited and detailed HC financial statements (see Chamisa 2007). This unique reporting practice offers opportunities to provide better insights on the relative and incremental value relevance of $\mathrm{HC}$ and IA amounts. Our dataset avoids problems that prior studies have faced, such as the following: (a) estimating unreported IA (or HC) amounts, which leads to measurement errors, (b) testing for relative value relevance when one dataset (IA or HC) is reported in the notes, and (c) using single-period datasets that fail to account for 'the learning effect' (see Section 3).

Using a sample of ZSE listed firms over the 2000-2005 period, we employ the returns and price models in the tests and report several interesting findings. In the first test, we compare the value relevance of the two sets of amounts. Similar to Kirkulak and Balsari (2009) and Filip and Raffournier (2010), we document that both HC and IA amounts are value relevant, but overall, 
HC amounts are superior to IA amounts. We next test whether IA data, particularly the recognized inflation gains and losses, provide incremental information content beyond that provided by HC amounts. Konchitchki $(2011$; 2013) shows that the unrecognized gains and losses have substantial implications for valuation. In essence, our tests amount to a decomposition of the IA statements into their HC amounts as well as inflation gains and losses. This analysis is analogous to prior studies, such as Sloan (1996) and Barth et al. (2001), who show that models that disaggregate earnings into their components exhibit greater explanatory power. We find that recognized inflation gains and losses provide incremental information content, and we further demonstrate that the explanatory power of this incremental model is similar to that of the HC model but superior to that of the IA model. Overall, these results do not support IAS 29's contention, and they suggest that providing only IA amounts in a hyperinflationary economy leads to a loss of value-relevant information.

In our third test, we exploit our innovative setting to test whether the value relevance of HC and IA amounts change with the level of inflation. Within our study period, we can distinguish between two distinct periods of inflationary conditions: a relatively low inflation period (20002002 , with an average inflation rate of 90.9\%) and a relatively high inflation period (2003-2005, with an average inflation rate of 361.3\%) (see Table 1). We document powerful and interesting results. Whereas HC amounts exhibit significantly greater value relevance than IA amounts in the relatively low inflation period, the differences in value relevance are less distinguishable in the relatively high inflation period. Further, our evidence shows an increasing value relevance of the two sets of amounts as inflation levels increase, but the increase is greater for IA amounts. These results imply that in periods of higher inflation, investors fail to completely discriminate between the two measures, but they seem to attach greater value to IA amounts relative to low inflation periods.

Next, we apply the price model to examine the effects of inflation on the value relevance of earnings and equity book values. We find that whereas earnings obtained under both the $\mathrm{HC}$ and IA accounting systems have valuation relevance, book values are of value only under the IA accounting system. These findings are consistent with prior research demonstrating that the valuation weights of equity book values adjusted for inflation are greater than those of the HCbased book values (e.g., Hughes et al. 2004; Ashton et al. 2011; Konchitchki 2011). Thus, it appears that when investors are presented with HC financial statements, they 'fixate' on earnings and ignore the value of inflation gains and losses in nonmonetary assets, but they find the gains and losses informative under the IA system. This implies that when IA data are not available, 
investors fail to incorporate the information, possibly because inflation affects accounting amounts in complex and unfamiliar ways (Beaver and Landsman 1983).

Finally, while our analyses show that both HC and IA amounts have valuation implications, $\mathrm{HC}$ amounts appear to be more value relevant than IA amounts. One explanation for the greater value relevance of $\mathrm{HC}$ amounts may lie in their ability to help investors predict future economic outcomes in the valuation of equity (e.g., Barth et al. 2001; Curtis et al. 2015). Accordingly, we test for the relative power of the $\mathrm{HC}$ and IA amounts in predicting future cash flows from operations. Our results show that current HC earnings and cash flows are better predictors of future cash flows than current IA earnings and cash flows. Hence, it appears that the reason why investors price $\mathrm{HC}$ amounts better than IA amounts is that $\mathrm{HC}$ amounts are more informative in predicting future cash flows.

Our study contributes to the literature in a number of ways. First, it contributes to prior inflation accounting research that shows that even during a period in which inflation is relatively low, IA accounting information has substantial economic consequences for predicting future cash flows and stock valuation. It does so by providing evidence (a) that is consistent with prior research regarding the benefits of IA amounts (e.g., Konchitchki 2011) and (b) that indicates that the value relevance of IA amounts increases with inflation rates (e.g., Ashton et al. 2011). Second, for the first time, we provide evidence that investors attach greater value to $\mathrm{HC}$ amounts than to IA amounts in a relatively low inflation period, but they fail to distinguish between the two sets of amounts in a relatively high inflation period. Third, we extend prior work by documenting that the differences in the value relevance of HC and IA amounts stem from their ability to predict future cash flows from operations. Thus, we elucidate why investors may price $\mathrm{HC}$ and IA amounts differently. Fourth, we contribute to a long line of prior research that examines the relative and/or incremental information content of disaggregating earnings into their accrual and cash flow components (e.g., Sloan 1996; Barth et al. 2001). Our evidence, which documents that IA earnings decomposed into their $\mathrm{HC}$ as well as inflation gains and losses components provide greater valuation implications, offers new insights to the research.

Finally, our work contributes to a growing body of research on macro-accounting by examining the link from macroeconomic data (i.e., inflation) to firm-level data (i.e., information in earnings and book values). In particular, using published actual accounting amounts, we inform recent work on (1) how inflation affects firm-level performance, future cash flow prediction and stock returns (Konchitchki 2011; 2013; Curtis et al. 2015), (2) how the prediction 
of firm fundamentals is enhanced by integrating macro information (Konchitchki 2011; Li et al. 2014), and (3) how a firm's sensitivity to downward macroeconomic conditions affects its stock returns (Konchitchki et al. 2016). We also inform the research on a link that operates in the opposite direction, that is, from the micro- (firms) to the macro-level (e.g., Konchitchki and Patatoukas 2014a, b; Patatoukas 2014; Gallo et al. 2016) by providing evidence that inflation (a macro-level factor) affects the value relevance of firm-level accounting amounts.

The remainder of the paper is organized as follows. The next section discusses the study context, while Section 3 presents a review of the related literature. The research design and data are described in Section 4. The results are presented and discussed in Section 5. The last section presents the concluding remarks.

\section{Context of the study}

\subsection{Macroeconomic environment}

Beginning in 1997, Zimbabwe was embroiled in an economic crisis that was triggered largely by the land distribution policy, involvement in a war to support the government of Democratic Republic of Congo, severe droughts and inappropriate fiscal policies (Robertson 2003; Noko 2011; Mangena et al. 2012). The land distribution policy, war, and fiscal policies were disapproved by multilateral financial institutions (i.e., International Monetary Fund, IMF, and World Bank) and most developed countries. As the government continued its policies, its relationship with developed countries and multilateral financial institutions was severely strained, which led to a suspension of balance-of-payment support in 2000 (Robertson 2003; African Development Bank, ADB 2007). In addition, the government's decision to pull out of the Commonwealth led to further isolation. The US and the European Union eventually imposed targeted sanctions on the country, and external financial support became confined to only humanitarian assistance. Against this backdrop, the government turned to excessive use of bank financing, which fueled money supply growth and an upsurge in inflation. In the 2000-2002 period, year-over-year inflation increased from $55.9 \%$ to $140.1 \%$. Then, following the disputed presidential elections in 2002, it dramatically shot up to $431.7 \%$ in 2003 before falling to $302.1 \%$ in 2005 (see Table 1). These high rates of inflation, coupled with a fall in the productivity of key sectors such as agriculture and manufacturing, contributed to the contraction in the economy. In particular, real GDP shrunk by $2.7 \%$ to $7.9 \%$ in the $2000-2002$ period and then by $3.8 \%$ to $10.4 \%$ 
in the 2003-2005 period, representing an overall decline of 34.5\% between 2000 and 2005 (see Table 1).

\section{Insert Table 1 About Here}

The post-2005 period witnessed further economic deterioration and an unprecedented upsurge in inflation. To stabilize inflation, the Reserve Bank of Zimbabwe revalued the Zimbabwe dollar (Z\$) three times between 2006 and 2009 before officially scrapping it on 12 April 2009 and replacing it with a multi-currency system, with the US\$ as the main currency (Noko 2011). The introduction of the multi-currency system brought the hyperinflation to an end. During the 2009-2013 period, the average annual inflation rate was 3.3\%, while real GDP grew by more than $8 \%$ per year (Brixiova and Ncube 2014).

\subsection{Financial accounting and reporting}

In Zimbabwe, the regulatory framework for financial accounting and reporting rests on three pillars: the Companies Act (Chapter 24:03), accounting standards and the ZSE listing requirements. However, the responsibility for accounting standards lies with the ICAZ, which was established in 1918 and joined the International Accounting Standards Committee (IASC) in 1974 (Chamisa 2000). The ICAZ has delegated the development of accounting standards to the Zimbabwe Accounting Practices Board (ZAPB), which was set up in $1977 .{ }^{4}$ Since its inception, ZAPB has developed local accounting standards by adopting IASs/IFRSs without modification but after following "due process" (Chamisa 2000). Given that IASs/IFRSs are considered high quality standards (e.g., Hellstrom 2006; Barth et al. 2008), we can infer that accounting information provided by ZSE listed firms is of high quality. However, Hellstrom (2006) and Barth et al. (2008) argue that the mere adoption of high-quality accounting standards may not result in high-quality accounting information if the standards are not enforced and complied with. In Zimbabwe, compliance with the IASs/IFRSs and the ZSE listing requirements is enforced by the ZSE Monitoring Panel, which was set up jointly by the ZSE and ZAPB. In addition, the Companies Act (Chapter 24:03) requires listed firms to comply with the ZSE listing

\footnotetext{
4 ZAPB members are drawn from accounting professional bodies, the business community and the ZSE (Chamisa 2000).
} 
requirements. Empirical research shows that compliance with IASs/IFRSs and ZSE listing rules is very high (see Chamisa 2000; Owusu-Ansah 2000; Mangena and Tauringana 2007). This, coupled with the fact that most ZSE listed firms are audited by the Big Four international accounting firms, suggests that the accounting information is of high quality ${ }^{5}$.

\subsection{Stock market functioning}

The value relevance of accounting information is affected by the operational efficiency of stock markets (Kothari 2001; Hellstrom 2006). The ZSE is one of the oldest stock exchanges in Africa; established in 1896, it was initially intended to provide a forum through which mining companies could raise equity financing to fund operations (Mangena and Tauringana 2007). However, today, the majority of listed companies are non-mining. The exchange is small by international standards, but is the third largest, most active and liquid stock exchange in Africa (World Bank 2003; Senbet and Otchere 2008). According to Senbet and Otchere (2008), the market capitalization ratio (a measure of size) ranged from 32.9\% of GDP in 2000 to approximately $70.3 \%$ of GDP in 2005 (see Table 2), making it the third largest in Africa after the Egyptian Stock Exchange (EGSE) and the Johannesburg Securities Exchange (JSE). The growth in the ratio coincided with an increase in the number of listed firms, from 71 to 79 , in the same period. In terms of market activity, Senbet and Otchere (2008) indicate that the ZSE turnover ratio (the value of shares traded to market capitalization) ranged from $23.3 \%$ in 2000 to $15.3 \%$ in 2005 , declining with a contraction in the economy. This activity level is high in the context of Africa and is lower than only the EGSE and the JSE, with mean ratios of $27.7 \%$ and $47.3 \%$, respectively.

\section{Insert Table 2 About Here}

According to Hellstrom (2006) and Barth et al. (2008), an important feature of stock market functioning and the value relevance of accounting numbers relates to the timely release of information. In this regard, the ZSE Listing Rules (2002) require listed firms to submit to the ZSE and to all shareholders copies of the audited annual reports by end of the third month after

\footnotetext{
${ }^{5}$ In our sample, all ZSE listed firms (except one) were audited by one of the Big Four accounting firms (Deloitte and Touche, Ernest \&Young, KPMG and PwC).
} 
their fiscal year-end. ${ }^{6}$ In the event that a firm fails to meet this deadline, the ZSE requires that a preliminary report be published in the national press and distributed to all shareholders, even if the report is unaudited. Owusu-Ansah (2000) shows that 98\% of ZSE listed firms publish annual reports by the regulatory deadline, implying that the accounting numbers released by these firms are timely and are likely associated with stock prices. Oppong (1993) confirms this association between stock prices and earnings in Zimbabwe.

\section{Literature review}

\subsection{Relation to prior studies}

Our work relates to three streams of literature on the link between accounting amounts and stock returns and/or values of equity. One stream, the one most closely related to our study, examines the value relevance of IA accounting amounts. In the 1970s and 1980s, a major debate in the UK and US focused on whether to recognize the effects of inflation in published financial statements. This culminated in the introduction of accounting standards that required publication of IA amounts as supplements to $\mathrm{HC}$ statements. ${ }^{7}$ Consequently, several studies examined the incremental value relevance of IA amounts (e.g., Beaver et al. 1980; Watts and Zimmerman 1980; Appleyard and Strong 1984; Board and Walker 1984; Skerratt and Thompson 1984; Brayshaw and Miro 1985; Murdoch 1986). Overall, the results suggest that IA amounts "are inconsequential for making financial decisions" (Konchitchki 2011: 1046) and are attributed to a 'learning effect'. The studies focused on IA effects on contemporaneous annual and shortwindow returns and thus failed to capture investors' learning on how to process and use IA data (Watts and Zimmerman 1980). The most recent studies by Konchitchki (2011; 2013) consider longer-horizon periods and document that IA data, even in periods of low inflation, have valuation implications. However, because IA data in these studies are estimated, the results are prone to measurement errors (Murdoch 1986). In addition, by estimating IA amounts, the studies disregard the often-highlighted problem that investors ignore IA amounts when they are

\footnotetext{
${ }^{6}$ In addition, listed firms are required by the Companies Act to publish their results (in summary form) in national newspapers.

${ }^{7}$ The standards include Statement of Standard Accounting Practices (SSAP) 16 in the UK and Statement of Financial Accounting Standard (SFAS) 33 in the US, both of which are now defunct. During the $1970 \mathrm{~s}$ and $1980 \mathrm{~s}$, the inflation rates ranged between $3.43 \%$ and $24.24 \%$ in the UK and between $1.86 \%$ and $13.51 \%$ in the US (Bartley and Boardman 1990; IMF 2010).
} 
unavailable. ${ }^{8}$ Further, the studies address the question of whether inflation gains and losses have incremental information, but they do not address the relative value relevance of HC and IA amounts. Thus, we contribute by using actual published inflation data and examining both the relative and incremental value relevance of IA and $\mathrm{HC}$ amounts.

Outside the UK and US, a number of studies examine the value relevance of accounting amounts in hyperinflationary economies, such as Mexico (Rivera 1987), Israel (Barniv 1999), Turkey (Kirkulak and Balsari 2009) and Romania (Filip and Raffournier 2010). These studies extend prior UK/US work by exploring not only the incremental but also the relative value relevance of HC and IA amounts. On the whole, the results indicate that both $\mathrm{HC}$ and IA amounts are value relevant and have incremental value beyond that of the other. However, the results are conflicting as to which amounts are more value relevant. Rivera (1987) and Barniv (1999) find that IA amounts are more value relevant and suggest that $\mathrm{HC}$ amounts must either be reported as supplementary information or supplanted by IA amounts and not reported at all. In contrast, Kirkulak and Balsari (2009) and Filip and Raffournier (2010) show that HC amounts are more value relevant and conclude that IA amounts should be reported as a supplementary to, instead of supplanting, $\mathrm{HC}$ amounts. As we noted earlier, these conflicting results might stem from measurement errors, data availability and the use of single-period datasets. Our dataset does not have these problems. Further, an important omission in these studies is that they do not analyze why either HC or IA amounts are more value relevant. We address this gap in our study.

The second stream of studies examines the value relevance of HC earnings and book values. In particular, our work relates to a stream of studies that tests whether the value relevance of earnings and book values has increased or decreased over time (e.g., Collins et al. 1997; Francis and Schipper 1999). These studies show that the value relevance of earnings has declined while that of book values has increased. Other related studies examine the relative and/or incremental value relevance of earnings and earnings disaggregated into their accruals and cash flow components. These studies show that models in which earnigs are disaggregated into accruals and cash flows exhibit greater value relevance (Finger 1994; Sloan 1996; Barth et al. 2001a; Bartov et al. 2001). We extend these studies by analyzing and comparing the value relevance of earnings and book values obtained from accounting systems that focus on different measurement

\footnotetext{
${ }^{8}$ This is because (a) such data are costly and more complicated to process than HC data (Beaver and Landsman 1983; Konchitchki 2011), and (b) the manner in which inflation impacts HC amounts is complex and potentially confusing (Beaver and Landsman 1983; Ashton et al. 2011).
} 
attributes. This is important given that Hughes et al. (2004) and Ashton et al. (2011) indicate that the use of $\mathrm{HC}$ amounts distorts the mapping of earnings and book values into equity values. These two studies theoretically show that even at low levels of inflation, valuation models that fail to capture inflation produce severe under-valuations. Thus, by considering both HC and IA data, we contribute to an understanding of how different accounting systems affect the value relevance of accounting amounts.

Finally, our work also relates to a growing stream of research on macro-accounting. ${ }^{9}$ In summary, some studies examine the macro to micro link, that is, the effects of information in macroeconomic data on the firm. For example, Konchitchki $(2011 ; 2013)$ and Curtis et al. (2015) show that inflation affects firms' accounting performance and has incremental information content for predicting future cash flows and stock valuation. Li et al. (2014) find that combining firm-level geographic segment data with country GDP growth forecasts leads to improvements in forecasting firm profitability. Konchitchki et al. (2016) demonstrate that the sensitivity of a firm to downward macroeconomic conditions has implications for its stock valuation. Other studies focus on the micro to macro link, that is, whether aggregate accounting data contain macroeconomic news that can be informative about GDP growth (Konchitchki and Patatoukas 2014a, b), stock market valuation (Patatoukas 2014) and monetary policy (Gallo et al. 2016). We add to these studies using a unique dataset and focusing at the firm level instead of the aggregate stock market level. This important because the focus on the stock market level "masks considerable heterogeneity in the way inflation affects individual stocks" given that the inflation effects on the firm depend on its assets and liabilities structures (Konchitchki 2013: 41).

\subsection{The valuation effects of $H C$ and $I A$ accounting amounts}

The IASB conceptual framework and prior studies suggest that the role of accounting information is to help investors (and creditors) predict a firm's future cash flows (Sloan 1996; Barth et al. 2001a; Bartov et al. 2001; IASB 2011; Curtis et al. 2015). In this context, Barth et al. (2001a) suggest that stock prices reflect investors' assessment of firms' ability to generate future cash flows. In this study, we conceptualize HC and IA amounts as two alternative measures that investors can use to predict future cash flows and make investment decisions.

\footnotetext{
${ }^{9}$ For a general summary of this work, see Konchitchki (2016).
} 
Thus, depending on how informative the measure is for predicting cash flows, each of the two measures might be value relevant, and/or one may be more value relevant than the other.

Focusing on the value relevance of IA amounts, normative theory suggests that $\mathrm{HC}$ amounts are problematic under inflationary conditions because they are not adjusted for inflation (e.g., Bartley and Boardman 1990; Konchitchki, 2011). Thies and Sturrock (1987) show that HC data overstate earnings and misrepresent the financial positions of firms in periods of high inflation. Hughes et al. (2004) and Ashton et al. (2011) argue that inflation creates a mismatch of HCbased allocated expenses (e.g., depreciation) and current revenue in determining earnings. This mismatch distorts the mappings from accounting earnings and book values into equity valuation, leading to loss of value-relevant information. They show that the valuation weights of $\mathrm{HC}$ amounts are affected by inflation such that valuation models using $\mathrm{HC}$ data result in the mispricing of stocks. Konchitchki $(2011$; 2013) explains why IA amounts embed valuable information for investors. The studies argue that because $\mathrm{HC}$ amounts do not capture inflation gains and losses that accumulate in assets over time, they result in a loss of value-relevant information. In particular, Konchitchki (2011: 1047) suggests that inflation gains and losses "can translate to future cash flows because higher unrecognized inflations gains.....result in higher cash flows from operations when the assets are used ...or sold..." and then shows a positive link between inflation gains and losses and future cash flows and stock returns. Konchitchki (2013) further provides an example of cash, explaining the substantial cash erosion that is unrecognized under HC but does affect IA accounts. To the extent that IA amounts are (ex ante) more informative than $\mathrm{HC}$ amounts, we predict that IA data will be more value relevant.

The assumption we make above is that investors are rational regarding the effects of inflation and thus may fully impound IA amounts when predicting future cash flows and undertaking stock valuations. This assumption is supported by Carsberg and Day (1984), who argue that the value relevance of accounting data depends on the extent to which they are used. Intuitively, this is appealing given that in our study setting, both IA and HC amounts are provided side-by-side in financial statements. The availability of IA amounts (in our study) eliminates the oftenhighlighted problem that investors ignore IA amounts when they are unavailable because such data are costly and more complicated to process than HC data (Beaver and Landsman 1983; Feyr and Tyran 2001; Ritter and Warr 2002). In contrast, however, we suggest that even though IA amounts are published, investors may still fail to fully impound the data into stock valuation. This can occur because the manner in which inflation impacts $\mathrm{HC}$ accounting amounts is complex (Beaver and Landsman 1983; Ashton et al. 2011); hence, investors may be confused 
about the implications of IA amounts for the firm's future cash flows. This complexity view appears to resonate with one of the key arguments made by preparers and users of financial statements lobbying against the adoption of IAS 29 in Zimbabwe- that is, "users were more comfortable with HC financial statements" (Chamisa et al. 2012: 7). Further, Chamisa (2007) finds that Zimbabwean analysts made little use of IA amounts in making investment decisions. Similar results are reported by Berliner (1983) and Maksy (1984) in the US, who show that analysts and banks, respectively, made little use of IA amounts. In this context, we make two predictions. First, if investors make little use of IA amounts, HC amounts will be more value relevant than IA amounts. Second, if investors primarily use HC amounts, as reported by Chamisa (2007), the information in the recognized inflation gains and losses will have incremental value relevance beyond that of $\mathrm{HC}$ amounts.

\section{Research design and data}

\subsection{Empirical models}

We test for both the relative and incremental value relevance of two sets of accounting measures: HC and IA amounts. Following prior literature (Biddle et al. 1995; Francis and Schipper 1999), we measure value relevance based on the ability of (a) earnings to explain annual stock returns (the returns model) and (b) earnings and book values of equity to explain stock prices (the price model). Kothari and Zimmerman (1995) argue that price and returns models address related but different research issues regarding value relevance. While price models examine what is reflected in firm value, returns models test for the timeliness of accounting data in predicting stock returns. In both instances, to the extent that IA amounts provide higher-quality information than HC amounts, as argued by Ashton et al. (2011), IASB (2011) and Konchitchki (2011), our prediction is that IA models will exhibit greater explanatory power than HC models. We also expect, consistent with Konchitchki (2011), that recognized inflation gains and losses will have incremental information content beyond that of $\mathrm{HC}$ amounts. Our first model is the returns model (Easton and Harris 1991), with fixed time effects:

$$
\begin{aligned}
& \text { RETURN }_{i t}=\alpha_{0}+\alpha_{1} \text { EARNINGS }_{i t}+\alpha_{2} \text { YearDummies }+\varepsilon_{i t} \\
& \text { RETURN }_{i t}=\alpha_{0}+\alpha_{1} \text { EARNINGS }_{i t}+\alpha_{2} \text { EIGLS }_{i t}+\alpha_{3} \text { YearDummies }+\varepsilon_{i t}
\end{aligned}
$$

where $i$ and $t$ denote firm and year, respectively; RETURN $N_{i t}$ denotes the stock return of firm $i$ over the 12-month period ending 4 months after the fiscal year-end (measured as the change in 
stock price plus dividend per share for the fiscal year and scaled by the stock price at the beginning of the fiscal year); EARNINGS $S_{i t}$ is firm $i$ 's reported basic earnings per share, calculated in accordance with IAS 33, 'Earnings per share', for fiscal year $t$; and $E I G L S_{\text {it }}$ is the recognized inflation gains and losses in earnings (i.e., the difference between $\mathrm{HC}$ and IA earnings). To mitigate the size or scale effects, we deflate $E A R N I N G S_{i t}$ and $E I G L S_{i t}$ by the stock price at the start of the firm's fiscal year (see Dechow 1994).

Our second model expresses stock prices as a function of earnings and equity book values (price model) (Ohlson 1995) and is specified as follows:

$$
\begin{aligned}
\text { PRICE }_{i t} & =\alpha_{0}+\alpha_{1} \text { EARNINGS }_{i t}+\alpha_{2} \text { BOOK VALUES }_{i t}+\alpha_{3} \text { YearDummies }+\varepsilon_{i t} \\
\text { PRICE }_{i t} & =\alpha_{0}+\alpha_{1} \text { EARNINGS }_{i t}+\alpha_{2} \text { BOOK VALUES } \\
i t & +\alpha_{3} \text { EIGLS }_{i t} \\
& +\alpha_{4} \text { BVIGLS }_{i t}+\alpha_{5} \text { YearDummies }+\varepsilon_{i t}
\end{aligned}
$$

where $P R I C E_{\mathrm{it}}$ is the price per share for firm $i$ at the end of the 4-month period after the fiscal year-end; EARNINGS $S_{\mathrm{it}}$ and $E I G L S_{\mathrm{it}}$ are as defined in Equations 1 and 2; BOOK VALUES $S_{\mathrm{it}}$ is the reported book values of equity per share; and $B V I G L S_{\mathrm{it}}$ is the recognized inflation gains and losses in equity book values (i.e., the difference between HC and IA equity book values). All variables are deflated by the stock price at the start of the firm's fiscal year.

For Equations 1 and 3, we run two non-nested regression models, each separately testing whether HC and IA amounts are value relevant. We then compare, using the Vuong (1989) test, the adjusted $R^{2}$ s of the two models to determine which one is more value relevant. The Vuong test is designed to compare two models' fit to the same data by maximum likelihood (see Dechow 1994). The null hypothesis is that the value relevance of HC and IA amounts are equal. A significant Vuong's Z-statistic indicates that one model fits the data better than the other. In Equations 2 and 4, we examine whether inflation gains and losses in earnings $\left(E I G L S_{\mathrm{it}}\right)$ and in both earnings and equity book values ( $E I G L S_{\mathrm{it}}$ and $\left.B V I G L S_{\mathrm{it}}\right)$, respectively, provide incremental information beyond that provided by HC amounts (herein referred to as the incremental content model). In essence, Equations 2 and 4 are analogous to a decomposition of the IA version of Equations 1 and 3 into $\mathrm{HC}$ as well as inflation gains and losses. We also compare the explanatory powers of Equations 2 and 4 to those of Equations 1 and 3, respectively, to establish which models have greater value relevance.

\subsection{Data and sample}


The data for our study relate to firms listed on the ZSE during the 2000-2005 period, when the annual inflation rate ranged between $55.9 \%$ and $431.7 \%$ (see Table 1 ). ${ }^{10}$ We obtained the data from two primary sources: (a) stock prices were extracted by hand from the Daily Price Data obtained from the ZSE, and (b) all accounting data were hand collected from annual financial statements. To ensure data accuracy, we engaged two research assistants to extract all data independently. The two datasets produced were then checked against one another by one of the authors, and any differences were investigated and corrected.

Annual reports of listed firms were gathered from a variety of sources, including the ZSE, stockbroker firms, transfer secretaries and head offices of listed firms. In line with prior studies (e.g., Gordon 2001; Kirkulak and Balsari 2009), we excluded financial firms (banks, insurance and mutual funds). We also excluded firms that did not comply with IAS 29, those with missing annual reports and those with missing stock prices. This sample selection procedure resulted in a final sample of 193 firm-years (see Table 3).

\section{Insert Table 3 About Here}

\section{Empirical results}

\subsection{Descriptive analysis}

Table 4 presents summary descriptive statistics for the entire pooled sample and for the partitioned periods. The table includes statistics showing both Z\$ and US\$ amounts (US\$ figures in brackets). The US\$ amounts are calculated by applying the annual average exchange rates to the $\mathrm{Z} \$$ amounts at the firm level and are provided for illustrative purposes only. In Panel A, we present the statistics for the stock prices and returns. For the entire sample, the means for stock prices and stock returns are Z\$5,032.82 (US\$1.73) and 1,843\% (7.01\%), respectively. In the partitioned period, the mean for stock prices is Z\$119.68 (US\$2.20) for the relatively low inflation period and Z\$8,586.09 (US\$1.39) for the relatively high inflation period. The mean stock returns are $870 \%(15.9 \%)$ and $2,547 \%$ (2.6\%) for the relatively low and high inflation periods, respectively. On the whole, the stock prices and stock returns indicate an increasing

\footnotetext{
${ }^{10}$ Our decision to limit the sample period to 2005 is underpinned by the fact that the post-2005 period saw the $Z \$$ being revalued in 2006,2008 and 2009 before it was scrapped and a multi-currency system was introduced (see Section 2.1). Thus, including data for the post-2005 period would have been problematic in drawing conclusions from the analyses.
} 
(decreasing) trend for ZS\$ (US\$) numbers, reflecting the effects of both the weakening of the $\mathrm{Z} \$$ against the US\$ and the increasing inflation over the study period.

In Panels B and C, we present the summary statistics for $\mathrm{HC}$ and IA amounts, respectively. We first report the descriptive statistics for the entire pooled sample. As would be expected, Panels B and C indicate that the mean earnings of Z\$346.43 (US\$0.125) per share under HC accounting are greater than the mean earnings of Z\$134.14 (US\$0.042) per share under IA accounting. Similarly, the mean HC book values of equity, at Z\$900.61 (US\$0.361) per share, are smaller than the Z\$1,534.36 (US\$0.604) per share under IA accounting. With regards to the relatively low and high inflation periods, we observe that the emerging story is similar to the entire pooled sample. That is, the earnings (book values) are greater (smaller) under the HC accounting system than under the IA accounting system. In all cases, the pair-wise tests for both Z\$ and US\$ amounts indicate that the mean differences between HC and IA amounts (Panels B and C) are significant at the $1 \%$ level or better.

\section{Insert Table 4 About Here}

\subsection{The association between earnings and stock returns}

In Table 5, Panels A to $\mathrm{C}$, we present the results of the returns model tests. These tests are run using pooled panel regressions with fixed time effects (year dummies). Panel A reports the results of the entire period (2000-2005), Panel B the relatively low inflation period (2000-2002), and Panel C the relatively high inflation period (2003-2005). The first two columns of Table 5 (Models 1 and 2) provide the results based on Equation 1, whose objective is to examine the relative value relevance of $\mathrm{HC}$ and IA amounts. The results in column 3 (Model 3) are based on Equation 2, which tests for the incremental information content of inflation gains and losses. In interpreting the results in Table 5, we first consider models testing for the relative value relevance of $\mathrm{HC}$ and IA amounts.

Insert Table 5 About Here 
With regard to the entire pooled period (2000-2005), the adjusted $\mathrm{R}^{2} \mathrm{~s}$ for HC and IA amounts demonstrate that both regression models have significant explanatory power. However, we observe that the adjusted $\mathrm{R}^{2}$ for the $\mathrm{HC}$ model $(62.4 \%)$ is greater than that for the IA model (44.1\%). The Vuong Z-statistic of 2.349 is positive and significant at 5\%, thereby rejecting IA amounts in support of $\mathrm{HC}$ amounts. These results are consistent with those reported by Kirkulak and Balsari (2009) and Filip and Raffournier (2010) in the context of Turkey and Romania, respectively, but not with those of Rivera (1987) or Barniv (1999), who find that IA amounts are more value relevant in Mexico and Israel, respectively. We attribute the differences to the fact that in Barniv (1999), IA amounts were provided as the primary statements, while HC amounts were provided in notes to the accounts. This, as noted by Murdoch (1986) and Biddle et al. (1995), makes their conclusions questionable, as unreported data or data in notes cannot be expected to be more relevant than fully reported data. Prior studies also suggest that investors fail to fully impound unreported data in their decision-making processes (Basu et al. 2010; Konchitchki 2011). As for Rivera (1987), the reason for the difference in the results between that study and ours could be that the Mexican accounting standard on inflation (unlike IAS 29) allowed firms the option to use either the replacement cost method or the price-level method. This means that Rivera's (1987) results may be affected by mixing amounts from different measurement systems.

In terms of the incremental content model (Model 3), we observe that the coefficient of inflation gains and losses (EIGLS) is -2.285 with a t-statistic of 2.87 (significant at the $1 \%$ level). This suggests that inflation gains and losses have information content for stock valuations. These results are consistent with Konchitchki (2011). Further, the adjusted $\mathrm{R}^{2}$ of the incremental content model, at $63.8 \%$, is greater than those for the HC model (Model 1) and IA model (Model 2), at $62.4 \%$ and $44.1 \%$, respectively. The Vuong Z-statistics derived from comparing the adjusted $\mathrm{R}^{2}$ for the incremental content model and those of the HC and IA models show that the model is superior to the IA model (Z-statistic of 2.426, significant at $5 \%$ level) but does not differ significantly from the HC model. There are two key points to note from these results. First, the results imply that whereas investors will not be deprived of relevant information by the publication of $\mathrm{HC}$ amounts alone in periods of inflation, the provision of IA amounts without HC amounts would lead to substantial loss of information for stock valuations. Second, they indicate that decomposing IA amounts into their $\mathrm{HC}$ amounts as well as inflation gains and losses has substantial economic consequences. These results are consistent with prior studies, such as Sloan (1996), Barth et al. (2001a) and Bartov et al. (2001), that show that decomposing 
aggregate earnings into their components provides incremental information content for investors. Overall, these results do not support IASB's contention that $\mathrm{HC}$ amounts are not useful and should be supplanted with IA amounts.

Next, we examine whether the relative and incremental value relevance of $\mathrm{HC}$ and IA accounts change with the level of inflation. To do this, we first partition our study period into two observable distinct periods of inflationary conditions: 2000-2002, a relatively low inflation period (average of $90.9 \%$ ), and 2003-2005, a relatively high inflation period (average of $361.3 \%$ ) [see Table 1]. To the extent that HC amounts are not useful in periods of high inflation, as suggested by IAS 29 and prior literature (e.g., Konchitchki 2011), we expect that the superior explanatory power of the IA models over that of the HC models is more pronounced in the 20032005 period than in the 2000-2002 period. Furthermore, we expect the value relevance of IA amounts to be greater than it is in the relatively low inflation period. Thus, we run the regressions for each of the two sub-periods; the results are shown in Panels B and C of Table 5.

In Panel B of Table 5, we present the results for the relatively low inflation period (20002002), and Panel C reports the results for the high inflation period (2003-2005). We note that for the low inflation period (Panel B), the adjusted $\mathrm{R}^{2} \mathrm{~s}$ are $30.7 \%$ for the $\mathrm{HC}$ model (Model 1) and $8.4 \%$ for the IA model (Model 2). The Vuong Z-statistic of 4.229 is positive and significant at the $1 \%$ level, indicating that $\mathrm{HC}$ amounts are more value relevant than IA accounts. Further, we find that the coefficient of earnings under the IA model is +0.892 with a t-statistic of 1.26 and is not significant, suggesting that IA earnings are of little or no value in the relatively low inflation period. In contrast, in the incremental content model (Panel B, Model 3), both earnings and inflation gains and losses (EIGLS) are significantly associated with stock returns. The coefficient of earnings is +6.507 with a t-statistic of 4.04 (significant at the $1 \%$ level), and that of EIGLS is -2.211 with a t-value of 2.33 (significant at the $5 \%$ level). Similar to the entire pooled sample, the Vuong Z-statistic of 3.636 (significant at the 1\% level) shows that the incremental content model dominates the IA model but is equivalent to the HC model. These results show, consistent with Konchitchki (2011), that IA amounts have benefits even in periods of low inflation, particularly when they are decomposed into HC amounts as well as inflation gains and losses.

Turning to the relatively high inflation period (Panel $\mathrm{C}$ of Table 5), we observe that the HC model's explanatory power $(63.1 \%)$ is greater than that of the IA model $(50.5 \%)$. Despite the seemingly sizable difference in the adjusted $\mathrm{R}^{2} \mathrm{~s}$, the Vuong Z-statistic of 1.458 is not significant; 
thus, the null hypothesis that the two models are equal is accepted. In addition, similar to Panels $\mathrm{A}$ and $\mathrm{B}$, we find that in the incremental content model (Panel C, Model 3), the coefficient of EIGLS is -3.347 with a t-statistic of 2.75 (significant at the $1 \%$ level), and the model's power, $65.2 \%$, is greater than that of both the HC and IA models. The Vuong Z-statistic of 1.707 between the incremental content model and the IA model is significant only at the $10 \%$ level, while it is not significant for the HC model. These findings suggest that investors fail to discriminate between the two sets of amounts in periods of relatively high inflation. One explanation for these findings is that over time, the 'learning effect' might have been 'partially realised' (Konchitchki 2011) — that is, in the early period (2000-2002), investors had not learned how to analyze and process IA amounts, but over time, they may have learned and understood the stock valuation implications of IA amounts. However, the fact that the explanatory powers of $\mathrm{HC}$ and IA models are indistinguishable implies that investors may be uncertain on how to fully incorporate IA data into stock valuation (e.g., Basu et al. 2010; Konchitchki 2011); otherwise, IA amounts would be more value relevant than $\mathrm{HC}$ amounts.

Another aspect of our findings is that in the high inflation period, the valuation weights of both the HC and IA amounts appear to have increased relative to the low inflation period. In this case, we note that the adjusted $\mathrm{R}^{2} \mathrm{~s}$ for both the HC and IA models have increased substantially, by $105.5 \%$ and $501.2 \%$, respectively. ${ }^{11}$ The incremental content model power also improves by $118.1 \%$, from 0.299 in the relatively low inflation period to 0.652 in the relatively high inflation period. These observations are also evident in the yearly pooled regressions reported in Table 8 , Panel A (see Section 5.5). Further, we note that the coefficient of earnings of +9.018 (t-statistic of 8.47) in the IA model becomes significant at the $1 \%$ level in the high inflation period, in contrast to the low inflation period. The fact that the value relevance of earnings (both $\mathrm{HC}$ and IA) increases over time contradicts prior value relevance studies (e.g., Collins et al. 1997; Francis and Schipper 1999). This may be because the Zimbabwe economy (a) is different and (b) was going through a significant contraction during the sample period employed in this paper; this could have caused several financial intermediaries to shut up shop. This might have led investors to start relying more on financial statements. Nevertheless, from these observations, we can infer that the value relevance of both $\mathrm{HC}$ and IA amounts increases with the level of inflation, but the increase is greater for IA amounts. In this context, our results seem to lend credence to the theory that the value relevance of IA data increases with inflation (Ashton et al.

\footnotetext{
${ }^{11}$ Computed as the change in the adjusted $\mathrm{R}^{2} \mathrm{~S}$ of the low inflation period relative to high inflation period.
} 
2011). Overall, these findings suggest that publishing IA amounts alone, as contended by the IASB, may deprive investors of value-relevant information.

\subsection{The association of earnings and equity book values with stock prices}

In this section, we focus on analyses of the relation between $\mathrm{HC}$ and IA amounts and stock prices. The results are reported in Table 6 (Panels A to C).

\section{Insert Table 6 About Here}

We note that $\mathrm{HC}$ amounts exhibit higher adjusted $\mathrm{R}^{2} \mathrm{~s}$ than IA accounts in all panels (Panels $\mathrm{A}$ to $\mathrm{C}$, Model 1 versus Model 2) (that is, for the entire period, relatively low inflation and high inflation periods). Similarly, the power of the incremental content model appears superior to that of both the HC and IA models in all panels. However, in all cases, the Vuong Z-statistics are not significant across all models. The null hypothesis is therefore accepted - that is, the value relevance of the two sets of amounts is equal. With regards to the individual variables, we also observe that whereas the valuation coefficients on EARNINGS are significant in both the HC and IA models, the coefficients on BOOK VALUES are not significant in all HC models (in all panels). In contrast, we find that in all IA models (Panels A to C), the coefficients of BOOK VALUES are significant at the $1 \%$ level. We further show that in the incremental content model (Model 3), the coefficients of the recognized inflation gains and losses in earnings (EIGLS) are not statistically significant, while those in book values of assets $(B V I G L S)$ are all significant at the 1\% level. These results support the work of Hughes et al. (2004) and Ashton et al. (2011), who demonstrate that the valuation weights of equity book values adjusted for inflation are greater than those of the HC-based book values. The authors attribute this to the fact that IA amounts reduce the loss of information associated with HC-based book values, leading to better mapping of book values into equity values. The results are also in line with those of Konchitchki (2011; 2013), who show that the inflation gains and losses from holding nonmonetary assets are value relevant and suggest that this stems from the fact that inflation gains and losses in the book value of assets can translate into future cash flows over time. We contend that under the HC accounting system, investors appear to 'fixate' on earnings (Sloan 1996) but find both earnings and book values informative under the IA accounting system. Overall, similar to the returns 
model, these findings show that both HC and IA amounts are value relevant and that their value relevance increases with increasing inflation rates. Thus, both HC and IA are informative about stock market prices.

\subsection{Relative ability of HC and IA amounts to predict future cash flows}

In the preceding sections, the results suggest that although both HC and IA amounts are value relevant, $\mathrm{HC}$ amounts exhibit greater value relevance than IA amounts. These results are inconsistent with normative theory (Thies and Sturrock 1987; Bartley and Boardman 1990; IASB 2011; Konchitchki 2011), and therefore, a natural question arises: what do investors see in $\mathrm{HC}$ amounts that leads them to price the information differently from IA amounts? As we noted earlier, prior research (Finger 1994; Sloan 1996; Dechow et al. 1998; Barth et al. 2001a; Bartov et al. 2001) suggests that the answer to this question lies in the ability of the two measures to predict future cash flows from operations. We follow these prior studies and make the first attempt to address the above question by testing the relative ability of current $\mathrm{HC}$ and IA amounts to predict future cash flows. However, in contrast to these studies, our primary focus in these analyses is not to determine whether current earnings or cash flows are a better predictor of future cash flows but to examine the relative predictive powers of $\mathrm{HC}$ and IA amounts on future cash flows from operations. We specify the following equations:

$$
\begin{aligned}
& \text { CASHFOW }_{i t+1}=\alpha_{0}+\alpha_{1} \text { EARNINGS }_{i t}+\alpha_{2} \text { YearDummies }+\varepsilon_{i t} \\
& \text { CASHFOW }_{i t+1}=\alpha_{0}+\alpha_{1} \text { CASHFLOW }_{i t}+\alpha_{2} \text { YearDummies }+\varepsilon_{i t}
\end{aligned}
$$

In addition, following Konchitchki (2011), we extend Equations 5 and 6 by introducing recognized inflation gains and losses to examine whether they provide incremental information. Thus, we estimate the following:

$$
\begin{array}{r}
\text { CASHFLOW }_{i+1}=\alpha_{0}+\alpha_{1} \text { EARNINGS }_{i t}+\alpha_{2} \text { EIGLS }_{i t}+\alpha_{3} \text { YearDummies }+\varepsilon_{i t} \\
\text { CASHFLOW } i t+1 \\
=\alpha_{0}+\alpha_{1} \text { CASHFLOW }_{i t}+\alpha_{2} \text { CASHIGLS }_{i t} \\
+\alpha_{3} \text { YearDummies }+\varepsilon_{i t}
\end{array}
$$

where $C A S H F O W_{i t+l}$ is future cash flows from operations per share for firm $i$, measured as the earnings adjusted for extraordinary items, depreciation and amortization scaled by the number of ordinary shares outstanding at the fiscal year-end $t+1 ; E A R N I N G S_{i t}$ and $E I G L S_{i t}$ are as defined 
in Equations 1 and 2; CASHFOW $i$ is the current cash flows from operations per share for firm $i$ at the end of fiscal year $t$; and CASHIGLS $S_{i t}$ is the difference between current HC and IA cash flows from operations. Table 7 presents the estimation results.

\section{Insert Table 7 About Here}

In Models 1 to 3, we present the results of estimating Equations 5 and 7 with current earnings as the explanatory variable, while in Models 4 to 6 , the explanatory variable is the current cash flows. In both the current earnings and cash flow models, we find that the adjusted $\mathrm{R}^{2} \mathrm{~s}$ are all higher for $\mathrm{HC}$ amounts than for IA amounts. With the exception of the relatively high inflation period (2003-2005), the Vuong Z-statistics are all positive and significant at 5\% or better, supporting the notion that $\mathrm{HC}$ amounts have a greater ability to predict future cash flows from operations than IA amounts. In the relatively high inflation period, the Vuong Z-statistics are only significant at $10 \%$, indicating that the difference in the power of the two amounts is marginal.

In the incremental content models (Models 3 and 6), the adjusted $\mathrm{Rs}^{2}$ in the entire pooled and partitioned periods are generally higher than those in the HC models (only slightly) and IA models. The Vuong Z-statistics confirm these observations, indicating that the power of the incremental model does not differ significantly from the $\mathrm{HC}$ model but is superior to the IA model in predicting future cash flows. These results are similar to those reported in Tables 5 and 6. The coefficient of EIGLS is significant at the 5\% level for the entire period and the 2003-2005 period and at only the 10\% level for the 2000-2002 period. Overall, our results suggest, consistent with Konchitchki (2011), that the information in inflation gains and losses embedded in earnings has predictive ability in terms of future cash flows. However, regarding the incremental content model in which the explanatory variable is current cash flows (Model 6), none of the coefficients of CASHIGLS is significant, suggesting that cash flow gains and losses provide no incremental value. These results are in line with those of Finger (1994) and Dechow et al. (1998), who also show that current earnings are better predictors of future cash flows than current cash flows. Taken together, the results appear to indicate that investors seem to find HC amounts to be better predictors of future cash flows than IA amounts. Thus, the difference in the 
value relevance of HC and IA amounts appears to stem from their ability to predict future cash flows.

\subsection{Robustness tests}

We carry out additional analyses to test the robustness of our results. First, we run yearly returns regressions for the years 2001 to $2005 .^{12}$ The results are reported in Table 8, Panel A. (We only provide the adjusted $\mathrm{Rs}^{2}$ and the related Vuong Z-statistics.)

\section{Insert Table 8 About Here}

We find that with the exception of 2003 , the adjusted $\mathrm{R}^{2} \mathrm{~s}$ for $\mathrm{HC}$ amounts remain greater than those of IA amounts in all years. In 2003 (the year with the highest inflation, 431.7\%), the adjusted $\mathrm{R}^{2} \mathrm{~s}$ are the lowest for both the $\mathrm{HC}$ and IA models, at $1.2 \%$ and $3.6 \%$, respectively (the only year in which the IA model has greater explanatory power than the HC). A potential explanation for the 2003 results is the dramatic rise in inflation, which may have forced the market to consider a greater use of IA amounts, and as inflation stabilized in 2004 and 2005, the market went back to using HC amounts more than IA amounts. Another feature of the yearly results is that, in contrast to prior work showing a decrease in the value relevance of earnings (e.g., Collins et al. 1997; Francis and Schipper 1999), the explanatory power of both HC and IA earnings appears to increase over time. This is consistent with our main analyses, where the power of the models increased in the 2003-2005 period relative to 2000-2002. Two possible reasons for the differences with prior studies can be proffered. First, as suggested by Hellstrom (2006), the differences may stem from investors in developing countries relying more on annual report information than those in developed countries because they have limited alternative sources for information. Second, they may be explained by the fact that the Zimbabwean economy is different and was going through a significant contraction and hyperinflation during the sample period examined in this paper.

Second, following these yearly results in Panel A, we consider 2003 to be a shock year for the stock market, so our results may be affected by the shocks. We therefore eliminate all 2003

\footnotetext{
${ }^{12}$ Due to the small number of observations, we do not run yearly regressions for 2000 .
} 
observations and re-run the regressions. The results are reported in Table 8, Panels B and C. (The results for 2000-2002 are not included here as these are the same as those in Table 5.) As observed, the findings reported earlier are substantially maintained.

Third, all our analyses above use stock prices or returns at the end of the fourth month after the fiscal year-end. Although Owusu-Ansah (2000) shows that ZSE listed firms take on average three months to publish their results, the Companies Act (Chapter 24:03) requires firms to publish their annual reports within six months of the fiscal year-end. We therefore re-run the models using stock prices or returns at the end of the sixth month after the fiscal year-end. We find that the results (not tabulated here) are similar to those reported in Sections 5.2 and 5.3. Finally, Barth et al. (1998) and Collins et al. (1999) demonstrate that firms with negative earnings have smaller earnings response coefficients than firms reporting positive earnings. Therefore, we eliminate all observations with negative earnings, and our results (not tabulated) are largely unchanged, although the power of the regressions is improved. All these additional tests indicate that our results are robust.

\section{Concluding remarks}

In this study, we examine the relative and incremental value relevance of HC and IA amounts in a hyperinflationary environment. Using both the returns and price model approaches, we find that both HC and IA amounts are value relevant for stock valuations, but overall, HC amounts are more value relevant. The differences in value relevance between the two sets of amounts appear to derive from their ability to predict future cash flows from operations. We show that whereas HC amounts exhibit significantly greater value relevance than IA amounts in a relatively low inflation period, the differences in value relevance are less distinguishable in a relatively high inflation period. We also find that the recognized inflation gains and losses have an incremental information content, and the power of the incremental content model is similar to that of the HC model but superior to that of the IA model. Finally, the value relevance of both $\mathrm{HC}$ and IA amounts increases with the level of inflation, and this increase appears greater for the IA amounts than for the HC amounts. Taken together, these findings suggest that the two sets of amounts are complements to one another rather than substitutes.

Our study complements prior literature that examines the value relevance of $\mathrm{HC}$ accounting amounts. This literature has shown that the disaggregation of earnings into accruals and cash 
flow components enhances the informativeness of earnings in terms of predicting future cash flows and stock valuation. We contribute to this literature by offering direct evidence on the relative and incremental usefulness of performance measures stemming from accounting systems that focus on different measurement attributes (i.e., $\mathrm{HC}$ and IA amounts). We also contribute to the inflation accounting literature by showing that IA amounts are value relevant even in relatively low inflation and that the value relevance of IA amounts increases with inflation rates. Our work also informs the recent growing research on macro-accounting by providing evidence on whether inflation information in earnings and equity book values at the firm level relates to stock returns and prices.

Finally, our findings contribute considerably to debates relating to appropriate inflation accounting policies in inflationary environments. This is particularly relevant because many countries, especially in the developing world, experience very high inflation (see Gordon 2001; Chamisa 2007; American Institute of Certified Public Accountants 2010). In particular, policy makers such as the IASB may want to consider requiring or encouraging firms operating in hyperinflationary economies to publish both $\mathrm{HC}$ and IA financial statements. We offer a number of reasons for this suggestion. First, overall, the evidence (including that from previous studies) demonstrates that both $\mathrm{HC}$ and IA amounts are value relevant. Second, permitting both HC and IA financial statements will help firms support the information needs of the different users of financial statements. Third, given that (a) IA financial statements are complex, unfamiliar and difficult to understand and interpret (Beaver and Landsman 1983) and (b) users require time to learn how to use IA data, we contend that publishing both $\mathrm{HC}$ and IA financial statements would facilitate a 'learning effect'. This is because with the two statements, users are readily able to assess the impact of inflation on the familiar HC statements. Finally, given the Zimbabwean experience, we consider that in a hyperinflationary economy, the incremental costs of publishing both accounts are potentially less than the benefits; otherwise, the majority of complying firms would not have voluntarily published both. Indeed, as Konchitchki (2011) notes, to prepare IA financial statements, preparers must first have $\mathrm{HC}$ statements. ${ }^{13}$ However, we urge caution in drawing conclusions about policy implications because policy makers consider information uses for purposes other than stock valuation (see Holthausen and Watts 2001; Barth et al. 2001b).

\footnotetext{
${ }^{13}$ Mandating an IA reporting system in a low inflation country like the US "may impose public- and firm-level costs that do not necessarily outweigh the benefits" (Konchitchki 2011: 1048).
} 


\section{References}

African Development Bank (2007). Zimbabwe - Country Dialogue Paper.

https://www.afdb.org/fileadmin/uploads/afdb/Documents/Project-and-Operations/ADBBD-WP-2007-40-EN-ZIMBABWE-2007-COUNTRY-DIALOGUE-PAPER.PDF.

Accessed 9 March 2017.

American Institute of Certified Public Accountants. (2010). Monitoring inflation status of certain countries. http://www.aicpa.org. Accessed 18 January 2011.

Appleyard, A. R., \& Strong, N. C. (1984). The impact of SSAP 16 current cost disclosures on security prices. In B. Carsberg \& M. Page (Eds.), Current cost accounting: The benefits and costs (pp. 235-244). London: Prentice-Hall International.

Ashton, D., Peasnell, K., \& Wang, P. (2011). Residual income valuation models and inflation. European Accounting Review, 20(3), 459-483.

Barniv, R. (1999). The value relevance of inflation-adjusted and historical cost earnings during hyperinflation. Journal of International Accounting, Auditing and Taxation, 8(2), 269-287.

Bartley, J. W., \& Boardman, C. M. (1990). The relevance of inflation adjusted data to the prediction of corporate takeovers. Journal of Business Finance and Accounting, 17(1), 53-72

Barth, M., Beaver, W., \& Landsman, W. (1998). Relative valuation roles of equity book value and net income as a function of financial health. Journal of Accounting and Economics, 25(1), $1-34$.

Barth, M., Cram, D. P., \& Nelson, K. K. (2001a). Accruals and the prediction of future cash flows. The Accounting Review, 76(1), 27-58.

Barth, M. E., Beaver, W. H., \& Landsman, W. R. (2001b). The relevance of the value relevance literature for financial accounting standards setting: Another view. Journal of Accounting and Economics, 31(1-3), 77-104.

Barth, M. E., Landsman, W. R., \& Lang, M. H. (2008). International accounting standards and accounting quality. Journal of Accounting Research, 46(3), 467-498.

Bartov, E., Goldberg, S. R., \& Kim, M. (2001). The valuation-relevance of earnings and cash flows: an international perspective. Journal of International Financial Management and Accounting, 12(2), 103-132.

Basu, S., Markov, S., \& Shivakumar, L. (2010). Inflation, earnings forecasts, and post-earnings announcement drift. Review of Accounting Studies, 15(2), 403-440.

Beaver, W. H., Christie, A. A., \& Griffin, P. A. (1980). The information content of SEC Accounting Series Release No. 190. Journal of Accounting and Economics, 2(2), 127-157.

Beaver, W. H., Christie, A. A., \& Landsman, W. R. (1983). How well does replacement cost income explain stock return? Financial Analysts Journal, 39(2), 26-30.

Beaver, W. H., \& Landsman, W. R. (1983). Incremental Information Content of Statement 33 Disclosures. FASB Research Report. Norwalk, CT: FASB.

Berliner, R. W. (1983). Do analysts use inflation-adjusted information? Results of a survey. Financial Analysts Journal, 39(2), 65-72.

Biddle, G. C., Seow, G. S., \& Siegel, A. F. (1995). Relative versus incrémental information content. Contemporary Accounting Research, 12(1), 1-23. 
Board, J. G. L., \& Walker, M. (1984). The information content of SSAP 16 earnings changes. In B. Carsberg \& M. Page (Eds.), Current cost accounting: The benefits and costs (pp. 245252). London: Prentice-Hall International.

Brayshaw, R. E., \& Miro, A. R. O. (1985). The information content of inflation-adjusted financial statements. Journal of Business Finance and Accounting, 12 (2), 249-261.

Brixiova, Z., \& Ncube, M. (2014). The real exchange rate and growth in Zimbabwe: Does the currency regime matter? Working Paper, African Development Bank.

Carsberg, B., \& Day, J. (1984). The use of current cost accounting information by stockbrokers. In B. Carsberg \& M. Page (Eds.), Current Cost Accounting: The Benefits and the Costs (pp. 149-171). London: Prentice-Hall International.

Chamisa, E. (2000). The relevance and observance of the IASC standards in developing countries and the particular case of Zimbabwe. The International Journal of Accounting, $35(2), 267-286$.

Chamisa, E. (2007). The use and perceived usefulness of IAS 29 restated financial statements by Zimbabwean investment analysts. South African Journal of Accounting Research, 21(1), 57-79.

Chamisa, E., Mangena, M., Pamburai, H., \& Changunda, S. (2012). Financial reporting in hyperinflationary economies: Some determinants of accounting policy preferences by Zimbabwean corporates. Working paper, University Cape Town.

Collins, D. W., Maydew, E. L., \& Weisis, I. S. (1997). Changes in the value-relevance of earnings and book values over the past 40 years. Journal of Accounting and Economics, 24, $39-67$

Collins, D. W., Pincus, M., \& Xie, H. (1999). Equity valuation and negative earnings: The role of book value of equity. The Accounting Review, 74(1), 29-61.

Companies Act (Chapter 24:03). (1996). Harare: Government Printers.

Curtis, A., Lewis-Western, M.F. and Toynbee, S. (2015). Historical cost measurement and the use of DuPont analysis by market participants, Review of Accounting Studies, 20(3), 12101245.

Dechow, P. M. (1994). Accounting earnings and cash flows as measures of firm performancethe role of accounting accruals. Journal of Accounting and Economics, 18(1), 3-42.

Dechow, P. M., Kothari, S. P. and Watts, R. L. (1998). The relation between earnings and cash flows. Journal of Accounting and Economics, 25(2), 133-168.

Delta Corporation (Zimbabwe) Ltd (2007). Annual Report. http://www.delta.co.zw. Accessed 12 September 2013.

Easton, P. D., \& Harris, T. S. (1991). Earnings as explanatory variables for returns. Journal of Accounting Research, 29(1), 19-36.

Feyr, E., \& Tyran, J. R. (2001). Does money illusion matter? American Economic Review, 91(5), 1239-1262.

Filip, A., \& Raffournier, B. (2010). The value relevance of earnings in a transition economy: The case of Romania. The International Journal of Accounting, 45, 77-103.

Finger, C. A. (1994). The ability of earnings to predict future earnings and cash flow. Journal of Accounting Research, 32(2), 210-223.

Francis, J., \& Schipper, K. (1999). Have financial statements lost their relevance? Journal of Accounting Research, 37(2), 319-352. 
Gallo, L. A., Hann, R. N., \& Li, C. (2016). Aggregate earnings surprises, monetary policy, and stock returns. Journal of Accounting and Economics, 62(1): 103-120.

Gheyara, K., \& Boatsman, J. (1980). Market reaction to the 1976 replacement cost disclosures. Journal of Accounting and Economics, 2(2), 107-125.

Gordon, E. (2001). Accounting for changing prices: The value relevance of historical cost, price level, and replacement cost in Mexico. Journal of Accounting Research, 39(1), 177-200.

Hellstrom, K. (2006). The value relevance of financial accounting information in a transitional economy: The case of the Czech Republic. European Accounting Review, 15(3), 325-349.

Hughes, J., Liu, J., \& Zhang, M. (2004). Valuation and accounting for inflation and foreign exchange. Journal of Accounting Research, 42(4), 731-754.

Holthausen, R. W., \& Watts, R. L. (2001). The relevance of the value-relevance literature for financial accounting standard setting. Journal of Accounting and Economics, 31(1-3), 3-73.

International Accounting Standards Board (2011). A guide through International Financial Reporting Standards (IFRSs): Parts $A$ and B. London: International Financial Reporting Standards Foundation.

International Monetary Fund (2008). Report for selected countries and subjects: Zimbabwe. World Economic Outlook Database.

http:/www.imf.org/external/pubs/ft/weo/2008/02/weodata/weorept.aspx.

Accessed 17 December 2014.

International Monetary Fund (2010). Financial statistics. http://www.imfstatistics.org. Accessed 15 July 2011.

Kirkulak, B., \& Balsari, C. K. (2009). Value relevance of inflation-adjusted equity and income. The International Journal of Accounting, 44(4), 363-377.

Konchitchki, Y. (2011). Inflation and nominal financial reporting: Implications for performance and stock prices. The Accounting Review, 86(3), 1045-1085.

Konchitchki, Y. (2013). Accounting and the macroeconomy: the case of aggregate price-level effects on individual stocks. Financial Analysts Journal, 69(6), 40-54.

Konchitchki, Y. (2016). Accounting valuation and cost of capital dynamics: The theoretical and empirical macroeconomic aspects. Discussion of Callen. Abacus, 52(1), 26-34.

Konchitchki, Y., \& Patatoukas, P. N. (2014a). Taking the pulse of the real economy using financial statement analysis: Implications for macro forecasting and stock valuation. The Accounting Review, 89(2), 669-694.

Konchitchki, Y., \& Patatoukas, P. N. (2014b). Accounting earnings and gross domestic product. Journal of Accounting and Economics, 57(1), 76-88.

Konchitchki, Y., Luo, Y., Ma, M. L. Z., and Wu, F. (2016). Accounting-based downside risk, cost of capital, and the macroeconomy. Review of Accounting Studies, 21(1), 1-36.

Kothari. S. P., \& Zimmerman, J. L. (1995). Price and return models. Journal of Accounting and Economics, 20(2), 155-192.

Kothari, S. P. (2001). Capital market research in accounting. Journal of Accounting and Economics, 31(1-3), 105-231.

Li, N., Richardson, S., \& Tuna, I. (2014). Macro to micro: country exposures, firm fundamentals and stock returns. Journal of Accounting and Economics, 58(1), 1-20. 
Mangena, M., \& Tauringana, V. (2007). Disclosure, corporate governance and foreign share ownership on the Zimbabwe Stock Exchange. Journal of International Financial Management and Accounting, 18(2), 53-85.

Mangena, M., Tauringana, V., \& Chamisa, E. (2012). Corporate boards, ownership structure and firm performance in an environment of severe political and economic uncertainty. British Journal of Management, 23(Suppl), 23-41.

Maksy, M. M. (1984). The use of inflation-adjusted accounting data by US banks. Accounting and Business Research, 15(57), 37-43.

Murdoch, B. (1986). The information content of FAS 33 returns on equity. The Accounting Review, 61(2), 273-287.

Noko, J. (2011). Dollarization: The case of Zimbabwe. Cato Journal, 31(2), 339-365.

Ohlson, J. A. (1995). Earnings, book values, and dividends in equity valuation. Contemporary Accounting Research, 11(2), 661-687.

Oppong, A. (1993). Price-earnings research and the emerging capital markets: The case of Zimbabwe. The International Journal of Accounting, 28(10), 71-77.

Owusu-Ansah, S. (2000). Timeliness of corporate financial reporting in emerging capital markets: Empirical evidence from the Zimbabwe Stock Exchange. Accounting and Business Research, 30(3), 241-254.

Patatoukas, P. N. (2014). Detecting news in aggregate accounting earnings: implications for stock market valuation. Review of Accounting Studies, 19(1), 134-160.

Ritter, J. R., \& Warr, R. S. (2002). The decline of inflation and the bull market of 1982-1999. Journal of Financial and Quantitative Analysis, 37(1), 29-61.

Rivera, J. M. (1987). Price-adjusted financial information and investment returns in a highly inflationary economy: An evaluation. Advances in International Accounting, 1, 287-304.

Robertson, J. (2003). 'The Zimbabwean Economy: The current position and the way forward'. In R. Cornwell (Ed), Zimbabwe's Turmoil: Problems and Prospects. http://www.iss.co.za/Pubs/Monographs/No87?Chap3.pdf. Accessed 9 June 2008.

Senbet, L., \& Otchere, I. (2008). African Stock Markets. African Finance for the $21^{\text {st }}$ Century High-Level Seminar. IMF Institute and Joint African Institute.

https://www.imf.org/external/np/seminars/eng/2008/afrfin/pdf/senbet.pdf.

Accessed 10 March 2017.

Skerratt, L. C. L., \& Thompson, A. P. (1984). The market reaction to SSAP 16 current cost disclosures. In B. Carsberg \& M. Page (Eds.), Current cost accounting: The benefits and costs (pp. 289-319). London: Prentice-Hall International.

Sloan, R (1996). Do stock prices fully reflect information in accruals and cash flows about future earnings? The Accounting Review 71(3), 289-316.

Thies, C. F., \& Sturrock, T. (1987). What did inflation accounting tell us? Journal of Accounting, Auditing and Finance, 2(4), 375-391.

Vuong, Q. H. (1989). Likelihood ratio tests for model selection and non-nested hypotheses. Econometrica, 57(2), 307-333.

Watts, R. L., \& Zimmerman, J. L. (1980). On the irrelevance of replacement cost disclosures for security prices. Journal of Accounting and Economics, 2(2), 95-106. 
World Bank (2003). Report on the observance of standards and codes (ROSC): Corporate governance-Zimbabwe. http://www.worldbank.org/ifa/rocs_cg_zimbabwe.html. Accessed 9 June 2008.

World Bank (2016). Zimbabwe. http://data.worldbank.org/country/zimbabwe Accessed 10 March 2017.

Zimbabwe Stock Exchange (2000-2005). Zimbabwe Stock Exchange Handbooks, Harare.

Zimbabwe Stock Exchange Listing Rules (2002). Zimbabwe Stock Exchange, Harare. 
Table 1: Zimbabwe economic data: 2000-2005

\begin{tabular}{|c|c|c|c|c|c|c|}
\hline & 2000 & 2001 & 2002 & 2003 & 2004 & 2005 \\
\hline Gross domestic product - GDP (US\$ billion) & 6.446 & 6.837 & 7.153 & 8.706 & 8.956 & 6.274 \\
\hline Real GDP change $(\%)$ & -7.9 & -2.7 & -4.4 & -10.4 & -3.8 & -5.3 \\
\hline Average yearly inflation (\%) & 55.86 & 76.71 & 140.06 & 431.70 & 350.08 & 302.12 \\
\hline Average inflation: Period 2000-2002 (\%) & & & 90.9 & & & \\
\hline Average inflation: Period 2003-2005 (\%) & & & & & & 361.3 \\
\hline Average yearly exchange rate (Z\$ to US\$) & 44 & 55 & 55 & 826 & 4,837 & 8,000 \\
\hline
\end{tabular}

Sources: African Development Bank (2007); International Monetary Fund (2008); World Bank (2016). 
Table 2: Stock market data: 2000-2005

\begin{tabular}{lcccccc}
\hline & $\mathbf{2 0 0 0}$ & $\mathbf{2 0 0 1}$ & $\mathbf{2 0 0 2}$ & $\mathbf{2 0 0 3}$ & $\mathbf{2 0 0 4}$ & $\mathbf{2 0 0 5}$ \\
\hline Number of listed firms & 71 & 74 & 77 & 82 & 79 & 79 \\
Market capitalization ratio (\% of GDP) & 32.87 & 77.73 & 71.39 & 67.26 & 41.2 & 70.26 \\
Turnover ratio (\% of total market & 23.33 & 29.40 & 19.19 & 26.14 & 19.22 & 15.27 \\
capitalization) & & & & & & \\
\end{tabular}

Sources: Senbet and Otchere (2008); ZSE Handbooks (200-2005) 
Table 3: Sample selection procedure for Zimbabwe Stock Exchange listed firms

\begin{tabular}{lcccccc}
\hline & $\mathbf{2 0 0 0}$ & $\mathbf{2 0 0 1}$ & $\mathbf{2 0 0 2}$ & $\mathbf{2 0 0 3}$ & $\mathbf{2 0 0 4}$ & $\mathbf{2 0 0 5}$ \\
\hline & 71 & 74 & 77 & 82 & 79 & 79 \\
No. of firms listed on the ZSE at year-end & 6 & 9 & 10 & 10 & 10 & 10 \\
Less: Banks & 3 & 4 & 7 & 7 & 7 & 7 \\
Less: Insurance and mutual funds & 62 & 61 & 60 & 65 & 62 & 62 \\
Total non-financial firms & 46 & 25 & 19 & 28 & 24 & 24 \\
Less: Firms not complying with IAS 29* & 4 & 6 & 2 & 1 & 0 & 0 \\
Less: Firms with missing share price data & 12 & 30 & 39 & 36 & 38 & 38 \\
Final sample of non-financial firms & & & & &
\end{tabular}

Notes:

* These firms also include those with missing annual reports. The number is exceptionally high for 2000 because IAS 29 was effective in Zimbabwe for fiscal years beginning on or after 1 January 2000. Hence, for 2000, only firms with a December year-end were required to comply.

Sources: The Zimbabwe Stock Exchange Handbooks (2000-2005). 
Table 4: Descriptive statistics for the variables

\begin{tabular}{|c|c|c|c|c|c|c|c|c|}
\hline & \multicolumn{4}{|c|}{ Z\$ Amounts } & \multicolumn{4}{|c|}{ US\$ Equivalent } \\
\hline & Mean & Std dev & Min & Max & Mean & Std & Min & Max \\
\hline \multicolumn{9}{|l|}{ Panel A: Stock prices and returns } \\
\hline $\begin{array}{l}\text { Stock prices }(\$) \text { : } \\
\text { L............. Entire pooled sample } \\
\text { Low inflation period } \\
\text { High inflation period }\end{array}$ & $\begin{array}{r}5,032.82 \\
119.68 \\
8,586.09\end{array}$ & $\begin{array}{r}36,594.55 \\
417.07 \\
47,811.16\end{array}$ & $\begin{array}{r}.32 \\
.32 \\
6.50\end{array}$ & $\begin{array}{r}500,000.00 \\
3,600.00 \\
50,000.00\end{array}$ & $\begin{array}{l}1.73 \\
2.20 \\
1.39\end{array}$ & $\begin{array}{l}6.826 \\
7.595 \\
6.230\end{array}$ & $\begin{array}{l}.003 \\
.007 \\
.003\end{array}$ & $\begin{array}{l}65.45 \\
65.45 \\
62.50\end{array}$ \\
\hline $\begin{array}{l}\text { Stock returns }(\%) \text { : } \\
\ldots \ldots \ldots \ldots \ldots \text { Entire pooled sample } \\
\text { Low inflation period } \\
\text { High inflation period }\end{array}$ & $\begin{array}{r}1,843 \\
870 \\
2,547\end{array}$ & $\begin{array}{l}5,154 \\
1,716 \\
6,529\end{array}$ & $\begin{array}{l}-.73 \\
-.54 \\
-.73\end{array}$ & $\begin{array}{l}46,329 \\
12,912 \\
46,329\end{array}$ & $\begin{array}{r}.0701 \\
.159 \\
.026\end{array}$ & $\begin{array}{l}.215 \\
.312 \\
.010\end{array}$ & $\begin{array}{l}-.012 \\
-.012 \\
-.001\end{array}$ & $\begin{array}{l}2.35 \\
2.35 \\
.088\end{array}$ \\
\hline Panel B: Historical data (\$) & & & & & & & & \\
\hline $\begin{array}{l}\text { Earnings: } \\
\ldots \ldots \ldots . . \text { Entire pooled sample } \\
\\
\quad \text { Low inflation period }\end{array}$ & $\begin{array}{r}346.43 \\
7.55\end{array}$ & $\begin{array}{r}1,612.05 \\
14.81\end{array}$ & $\begin{array}{r}-668.00 \\
-1.42\end{array}$ & $\begin{array}{r}17,741.00 \\
108.67\end{array}$ & $\begin{array}{l}.125 \\
.139\end{array}$ & $\begin{array}{l}.279 \\
.271\end{array}$ & $\begin{array}{l}-.083 \\
-.026\end{array}$ & $\begin{array}{l}2.22 \\
1.98\end{array}$ \\
\hline High inflation period & 591.51 & $2,085.78$ & -668.00 & $17,741.00$ & .114 & .285 & -.084 & 2.22 \\
\hline $\begin{array}{l}\text { Book values: } \\
\ldots \ldots \ldots \ldots \text {. Entire pooled sample } \\
\text { Low inflation period }\end{array}$ & $\begin{array}{r}900.61 \\
26.27\end{array}$ & $\begin{array}{r}4,178.50 \\
55.675\end{array}$ & $\begin{array}{l}-.557 \\
-.557\end{array}$ & $\begin{array}{r}47,730.44 \\
359.62\end{array}$ & $\begin{array}{l}.361 \\
.488\end{array}$ & $\begin{array}{r}.864 \\
1.017\end{array}$ & $\begin{array}{l}-.01 \\
-.01\end{array}$ & $\begin{array}{l}6.54 \\
6.54\end{array}$ \\
\hline High inflation period & $1,532.94$ & $5,407.16$ & -.228 & $47,730.44$ & .268 & .724 & .01 & 5.97 \\
\hline
\end{tabular}

Panel C: Inflation-adjusted data

(\$)

Earnings:

......... Entire pooled sample

Low inflation period

$\begin{array}{rrrrrrrr}134.14 & 1,270.07 & -1,089.00 & 17,128.00 & .042 & .225 & -.641 & 2.14 \\ 1.19 & 9.84 & -35.27 & 28.51 & .022 & .179 & -.641 & .518 \\ 230.29 & 1,663.70 & -1,089.00 & 17,128.00 & .056 & .253 & -.174 & 2.141\end{array}$

High inflation period

130.29

Book values:

Entire pooled sample

Low inflation period

$1,534.36$

42.26

$6,012.54$

71.59

.753

$53,436.41$

481.59

$.604 \quad 1.152$

$.784 \quad 1.307$

$.003 \quad 8.756$

High inflation period

$\begin{array}{llll}2,613.47 & 7,728.36 & 2.264 & 53,436.41\end{array}$

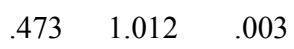

\section{Mean differences (B-C): Pair-wise tests}

\begin{tabular}{|c|c|c|}
\hline \multicolumn{3}{|l|}{ Earnings: } \\
\hline ...........Entire pooled sample & $3.164 * * *$ & $5.243 * * *$ \\
\hline Low inflation period & $3.905 * * *$ & $3.952 * * *$ \\
\hline High inflation period & $3.175 * * *$ & $3.514 * * *$ \\
\hline \multicolumn{3}{|l|}{ Book values: } \\
\hline ........ Entire pooled sample & $-3.195 * * *$ & $-7.102 * * *$ \\
\hline Low inflation period & $-5.455 * * *$ & $-5.546 * * *$ \\
\hline High inflation period & $-3.215 * * *$ & $-4.608 * * *$ \\
\hline
\end{tabular}

***Significant at the $1 \%$ level. Stock prices is the share price of the firm at the end of the fourth month after fiscal year-end. Stock return is the share return of the firm over the 12-month period ending 4 months after the fiscal year-end (measured as the change in price plus dividend per share for the year and scaled by the beginning share price). Earnings is the reported basic earnings per share, calculated in accordance with IAS 33 - Earnings per share. Book values is the reported book value of equity per share. $Z \$$ refers to the Zimbabwe dollar. 
Table 5: Results of pooled regression tests on the relative and incremental value relevance of $\mathrm{HC}$ and IA amounts with respect to stock returns

\begin{tabular}{|c|c|c|c|}
\hline $\begin{array}{l}\text { RETURN }_{i t}=\alpha_{0}+\alpha_{1} E A R N I \Lambda \\
\text { RETURN }_{i t}=\alpha_{0}+\alpha_{1} \text { EARNIN }\end{array}$ & $\begin{array}{l}\text { arDummies + } \\
G L S_{i t}+\alpha_{3} Y e c\end{array}$ & mmies $+\varepsilon_{i t}$ & $\begin{array}{l}\text { (1) } \\
\text { (2) }\end{array}$ \\
\hline Variables & $\begin{array}{c}\text { Model 1 } \\
\text { HC }\end{array}$ & $\begin{array}{c}\text { Model } 2 \\
\text { IA } \\
\end{array}$ & $\begin{array}{c}\text { Model 3 } \\
\text { Incremental } \\
\end{array}$ \\
\hline \multicolumn{4}{|l|}{ Panel A: Entire sample period (2000-2005) } \\
\hline Intercept & $\begin{array}{l}0.392 \\
(0.04)\end{array}$ & $\begin{array}{l}2.535 \\
(0.23)\end{array}$ & $\begin{array}{l}0.957 \\
(0.11)\end{array}$ \\
\hline EARNINGS & $\begin{array}{c}6.894 \\
\left(14.68^{* * *}\right)\end{array}$ & $\begin{array}{c}7.203 \\
\left(9.15^{* * *}\right)\end{array}$ & $\begin{array}{c}8.166 \\
\left(12.76^{* * *}\right)\end{array}$ \\
\hline EIGLS & & & $\begin{array}{c}-2.285 \\
(-2.87 * * *)\end{array}$ \\
\hline Fixed time effects & Included & Included & Included \\
\hline Number of observations & 193 & 193 & 193 \\
\hline F-ratio & $54.18 * * *$ & $26.23 * * *$ & $49.41 * * *$ \\
\hline Adjusted $\mathrm{R}^{2}$ & 0.624 & 0.441 & 0.638 \\
\hline Vuong’s Z-statistics: HC vs IA Model & & $2.349 * *$ & \\
\hline HC vs Incremental Model & & & 0.283 \\
\hline IA vs Incremental Model & & & $2.426^{* *}$ \\
\hline
\end{tabular}

Panel B: Low inflation period (2000-2002)

\begin{tabular}{|c|c|c|c|}
\hline Intercept & $\begin{array}{l}0.442 \\
(0.11)\end{array}$ & $\begin{array}{l}1.252 \\
(0.26)\end{array}$ & $\begin{array}{l}0.493 \\
(0.12)\end{array}$ \\
\hline EARNINGS & $\begin{array}{c}6.390 \\
(5.18 * * *)\end{array}$ & $\begin{array}{l}0.892 \\
(1.26)\end{array}$ & $\begin{array}{c}6.507 \\
(4.04 * * *)\end{array}$ \\
\hline EIGLS & & & $\begin{array}{c}-2.211 \\
\left(-2.33^{* *}\right)\end{array}$ \\
\hline Fixed time effects & Included & Included & Included \\
\hline Number of observations & 81 & 81 & 81 \\
\hline F-ratio & $12.82 * * *$ & $3.45 * * *$ & $9.53 * * *$ \\
\hline Adjusted $\mathrm{R}^{2}$ & 0.307 & 0.084 & 0.299 \\
\hline Vuong's Z-statistics: HC vs IA Model & & $4.229 * * *$ & \\
\hline HC vs Incremental Model & & & 0.748 \\
\hline IA vs Incremental Model & & & $3.636 * * *$ \\
\hline
\end{tabular}

Panel C: High inflation period (2003-2005)

\begin{tabular}{|c|c|c|c|}
\hline Intercept & $\begin{array}{l}-4.552 \\
(-0.68)\end{array}$ & $\begin{array}{l}-3.707 \\
(-0.48)\end{array}$ & $\begin{array}{c}-5.895 \\
(-0.907)\end{array}$ \\
\hline EARNINGS & $\begin{array}{c}6.909 \\
\left(11.55^{* * *}\right)\end{array}$ & $\begin{array}{c}9.018 \\
(8.47 * * *)\end{array}$ & $\begin{array}{c}8.771 \\
(9.82 * * *)\end{array}$ \\
\hline EIGLS & & & $\begin{array}{c}-3.347 \\
\left(-2.75^{* * *}\right)\end{array}$ \\
\hline Fixed time effects & Included & Included & Included \\
\hline Number of observations & 112 & 112 & 112 \\
\hline F-ratio & $64.29 * * *$ & $38.72 * * *$ & $53.02 * * *$ \\
\hline Adjusted $\mathrm{R}^{2}$ & 0.631 & 0.505 & 0.652 \\
\hline Vuong's Z-statistics: HC vs IA Model & & 1.458 & \\
\hline HC vs Incremental Model & & & 0.499 \\
\hline IA vs Incremental Model & & & $1.707 *$ \\
\hline
\end{tabular}

*** Significant at 1\% level; ** Significant at 5\% level; * Significant at $10 \%$ level. RETURNit denotes the share return of firm over the 12-month period ending 4-months after the fiscal year-end (measured as the change in price plus dividend per share for the year and scaled by the beginning share price). EARNINGS is the reported basic earnings per share, calculated in accordance with IAS 33 - Earnings per share for HC and IA amounts and EIGLS is the recognized inflation gains and losses in earnings (i.e., difference between HC and IA earnings). To mitigate the size or scale effects, we deflate EARNINGS and EIGLS by the share prices at the beginning of the returns annual window. 
Table 6: Results of pooled regression tests on the relative and incremental value relevance of $\mathrm{HC}$ and IA amounts with respect to share prices

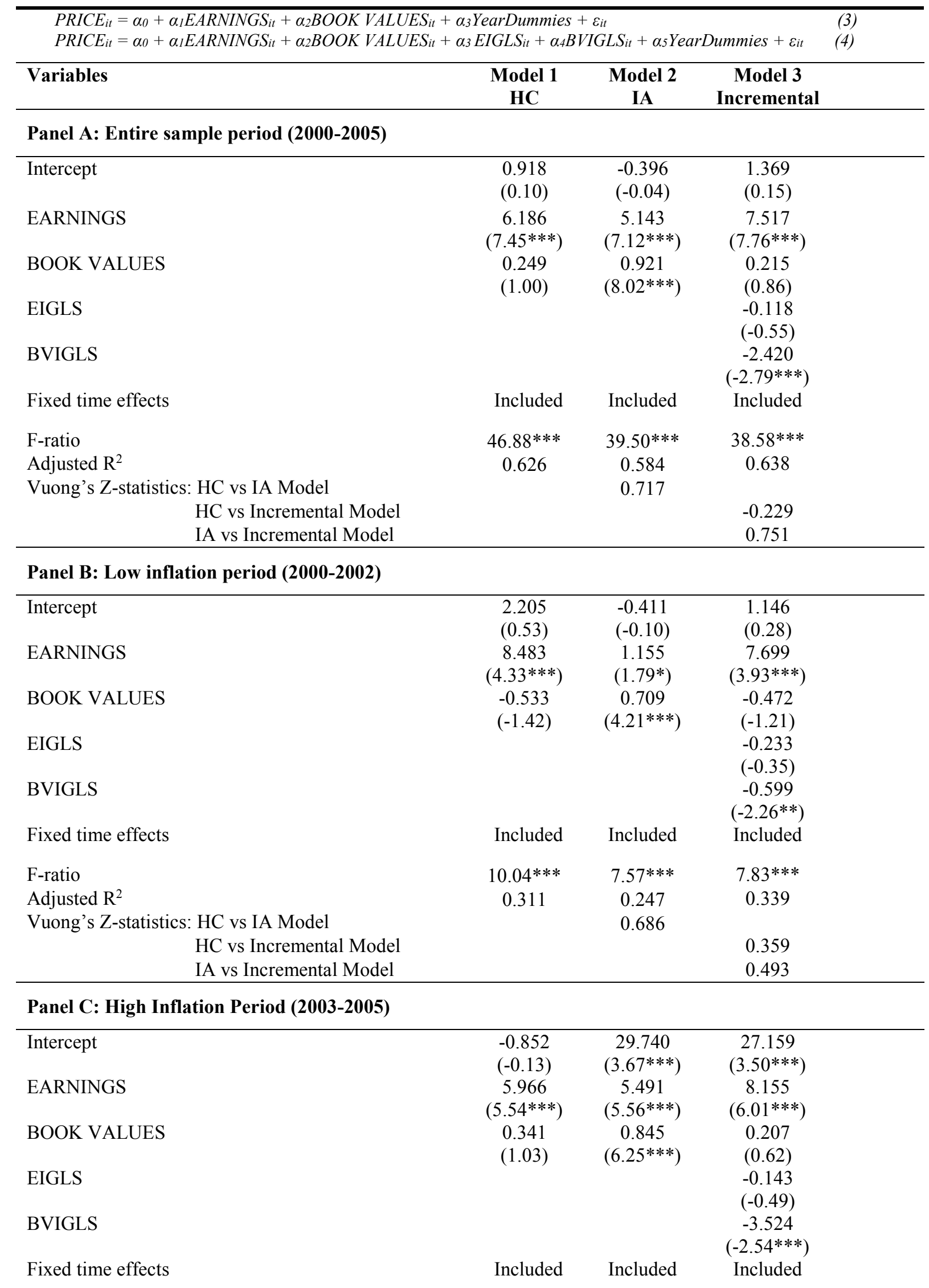


F-ratio

$\begin{array}{ccc}48.91 * * * & 45.09 * * * & 35.29 * * * \\ 0.633 & 0.614 & 0.650 \\ & 0.313 & \\ & & 0.299 \\ & & 0.244\end{array}$

Adjusted $\mathrm{R}^{2}$

Vuong's Z-statistics: HC vs IA Model

HC vs Incremental Mode

IA vs Incremental Model

*** Significant at $1 \%$ level; ** significant at $5 \%$ level; * significant at $10 \%$ level. PRICE denotes the price per share at the end of the fourth month after the fiscal year-end. EARNINGS is the reported basic earnings per share, calculated in accordance with IAS 33 - Earnings per share for $\mathrm{HC}$ and IA amounts, and $E I G L S$ is the recognized inflation gains and losses in earnings (i.e., difference between $\mathrm{HC}$ and IA earnings). $B O O K$ VALUES is the reported book values of equity per share for $\mathrm{HC}$ and IA amounts, and BVIGLS is the recognized inflation gains and losses in equity book values (i.e., difference between $\mathrm{HC}$ and IA book values of equity). We deflate all variables with the share price at the close of the previous year. 
Table 7: Results of pooled regression tests on the ability of $\mathrm{HC}$ and IA amounts to predict future cash flows from operations

\begin{tabular}{|c|c|c|c|c|c|c|}
\hline \multicolumn{6}{|c|}{$\begin{array}{l}\text { CASHFOW }_{i t+1}=\alpha_{0}+\alpha_{1} \text { EARNINGS }_{i t}+\alpha_{2} \text { YearDummies }+\varepsilon_{i t} \\
\text { CASHFOW }_{i t+1}=\alpha_{0}+\alpha_{1} \text { CASHFLOW } \\
\text { CASHFLOW }_{i t+1}=\alpha_{0}+\alpha_{1} \text { YearDummies }+\varepsilon_{i t} \\
\text { CASHFLOWINGS }_{i t+1}+\alpha_{2} \text { EIGLS }_{i t}+\alpha_{3} \text { YearDummies }+\alpha_{i t}+\alpha_{1} \text { CASHFLOW } \\
i t+\alpha_{2} \text { CASHIGLS } \\
i t+\alpha_{3} \text { YearDummies }+\varepsilon_{i t}\end{array}$} & $\begin{array}{l}\text { (5) } \\
\text { (6) } \\
\text { (7) } \\
(8)\end{array}$ \\
\hline \multirow[b]{2}{*}{ Variables } & \multicolumn{3}{|c|}{ Earnings models } & \multicolumn{3}{|c|}{ Current cash flow models } \\
\hline & $\begin{array}{c}\text { Model } 1 \\
\text { HC }\end{array}$ & $\begin{array}{c}\text { Model } 2 \\
\text { IA }\end{array}$ & $\begin{array}{c}\text { Model 3 } \\
\text { Incremental } \\
\end{array}$ & $\begin{array}{c}\text { Model } 4 \\
\text { HC }\end{array}$ & $\begin{array}{c}\text { Model } 5 \\
\text { IA }\end{array}$ & $\begin{array}{c}\text { Model 6 } \\
\text { Incrementa } \\
\text { I }\end{array}$ \\
\hline \multicolumn{7}{|c|}{ Panel A: Entire sample period $(2000-2005)(=132 \mathrm{obs})$} \\
\hline Intercept & $\begin{array}{c}-2.627 \\
(-11.78 * * *)\end{array}$ & $\begin{array}{c}-2.258 \\
(-10.12 * * *)\end{array}$ & $\begin{array}{c}-2.613 \\
(-11.84 * * *)\end{array}$ & $\begin{array}{c}-2.264 \\
(-10.18 * * *)\end{array}$ & $\begin{array}{c}-2.153 \\
(-8.95 * * *)\end{array}$ & $\begin{array}{c}-2.205 \\
(-9.57 * * *)\end{array}$ \\
\hline EARNINGS & $\begin{array}{c}2.034 \\
(5.73 * * *)\end{array}$ & $\begin{array}{c}2.092 \\
(3.42 * * *)\end{array}$ & $\begin{array}{c}2.866 \\
\left(5.20^{* * *}\right)\end{array}$ & & & \\
\hline CASH FLOWS & & & & $\begin{array}{c}1.405 \\
(3.54 * * *)\end{array}$ & $\begin{array}{c}0.484 \\
(0.469)\end{array}$ & $\begin{array}{l}0.898 \\
(1.39)\end{array}$ \\
\hline EIGLS & & & $\begin{array}{c}1.257 \\
\left(1.96^{* *}\right)\end{array}$ & & & \\
\hline CASHIGLS & & & & & & $\begin{array}{l}-0.713 \\
(-0.99)\end{array}$ \\
\hline Fixed time effects & Included & Included & Included & Included & Included & Included \\
\hline Number of observations & 132 & 132 & 132 & 132 & 132 & 132 \\
\hline F-ratio & $10.17 * * *$ & $5.46^{* * *}$ & $9.31 * * *$ & $5.64 * * *$ & $2.97 * *$ & $4.86^{* * *}$ \\
\hline Adjusted $\mathrm{R}^{2}$ & 0.259 & 0.145 & 0.276 & 0.154 & 0.069 & 0.150 \\
\hline $\begin{array}{l}\text { Vuong's Z-statistics: } \\
\text { HC vs IA data }\end{array}$ & & $2.438 * *$ & & & $3.098 * * *$ & \\
\hline HC vs Incremental data & & & -0.247 & & & -0.736 \\
\hline IA vs Incremental data & & & $2.633 * *$ & & & $2.517 * *$ \\
\hline \multicolumn{7}{|c|}{ Panel B: Low inflation period $(2000-2002)(=66$ obs) } \\
\hline Intercept & $\begin{array}{c}-2.795 \\
(-9.00 * * *)\end{array}$ & $\begin{array}{c}-1.991 \\
(-8.62 * * *)\end{array}$ & $\begin{array}{c}-2.704 \\
(-8.66 * * *)\end{array}$ & $\begin{array}{c}-2.028 \\
(-8.23 * * *)\end{array}$ & $\begin{array}{c}-1.831 \\
(-7.26 * * *)\end{array}$ & $\begin{array}{c}-1.996 \\
(-7.91 * * *)\end{array}$ \\
\hline EARNINGS & $\begin{array}{c}2.552 \\
(4.48 * * *)\end{array}$ & $\begin{array}{c}2.213 \\
\left(2.93^{* * *}\right)\end{array}$ & $\begin{array}{c}3.219 \\
(4.58 * * *)\end{array}$ & & & \\
\hline CASH FLOWS & & & & $\begin{array}{c}2.062 \\
(2.57 * *)\end{array}$ & $\begin{array}{l}0.819 \\
(1.29)\end{array}$ & $\begin{array}{c}1.808 \\
(2.03 * *)\end{array}$ \\
\hline EIGLS & & & $\begin{array}{l}1.249 \\
\left(1.68^{*}\right)\end{array}$ & & & \\
\hline CASHIGLS & & & & & & $\begin{array}{c}-0.661 \\
(-0.66)\end{array}$ \\
\hline Fixed time effects & Included & Included & Included & Included & Included & Included \\
\hline F-ratio & $10.31 * * *$ & $4.54 * *$ & $7.87 * * *$ & $3.53 * *$ & 1.70 & $2.48 *$ \\
\hline Adjusted $\mathrm{R}^{2}$ & 0.223 & 0.098 & 0.241 & 0.072 & 0.019 & 0.064 \\
\hline $\begin{array}{l}\text { Vuong's Z-statistics: } \\
\text { HC vs IA data }\end{array}$ & & $3.144 * * *$ & & & $4.651 * * *$ & \\
\hline $\mathrm{HC}$ vs Incremental data & & & -0.506 & & & -0.690 \\
\hline IA vs Incremental data & & & $3.230 * * *$ & & & $3.474 * * *$ \\
\hline \multicolumn{7}{|c|}{ Panel C: High inflation period $(2003-2005)(=66 \mathrm{obs})$} \\
\hline Intercept & $\begin{array}{c}-2.563 \\
(-11.01 * * *)\end{array}$ & $\begin{array}{c}-2.339 \\
\left(-10.40^{* * *}\right)\end{array}$ & $\begin{array}{c}-2.593 \\
\left(-11.45^{* * *}\right)\end{array}$ & $\begin{array}{c}-2.239 \\
(-10.21 * * *)\end{array}$ & $\begin{array}{c}-2.132 \\
\left(-8.06^{* * *}\right)\end{array}$ & $\begin{array}{c}-2.124 \\
\left(-8.46^{* * *}\right)\end{array}$ \\
\hline EARNINGS & $\begin{array}{c}1.791 \\
(3.95 * * *)\end{array}$ & $\begin{array}{c}3.137 \\
\left(3.00^{* * *}\right)\end{array}$ & $\begin{array}{c}3.721 \\
(3.77 * * *)\end{array}$ & & & \\
\hline CASH FLOWS & & & & $\begin{array}{c}1.204 \\
\left(2.66^{* *}\right)\end{array}$ & $\begin{array}{l}0.311 \\
(0.26)\end{array}$ & $\begin{array}{l}0.209 \\
(0.19)\end{array}$ \\
\hline EIGLS & & & $\begin{array}{c}2.584 \\
(2.19 * *)\end{array}$ & & & \\
\hline CASHIGLS & & & & & & -1.201 \\
\hline
\end{tabular}




\begin{tabular}{|c|c|c|c|c|c|c|}
\hline Fixed time effects & Included & Included & Included & Included & Included & $\begin{array}{l}(-0.96) \\
\text { Included }\end{array}$ \\
\hline F-ratio & $7.71 * * *$ & $5.28 * * *$ & $7.33^{* * *}$ & $4.58 * * *$ & 2.02 & $3.66 * * *$ \\
\hline Adjusted $\mathrm{R}^{2}$ & 0.236 & 0.165 & 0.280 & 0.142 & 0.045 & 0.141 \\
\hline $\begin{array}{l}\text { Vuong's Z-statistics: } \\
\text { HC vs IA data }\end{array}$ & & $1.895^{*}$ & & & $2.878 * *$ & \\
\hline $\mathrm{HC}$ vs Incremental data & & & -0.236 & & & -0.950 \\
\hline IA vs Incremental data & & & $2.182 *$ & & & $2.785 * *$ \\
\hline
\end{tabular}

*** Significant at $1 \%$ level; ** significant at $5 \%$ level; * significant at $10 \%$ level. CASH FLOW it $+1_{\text {denotes future cash flows }}$ from operations. EARNINGS it is the reported basic earnings per share, calculated in accordance with IAS 33 - Earnings per share for HC and IA amounts, and EIGLS is the recognized inflation gains and losses in earnings (i.e., difference between HC and IA earnings). CASH FLOW it is the current cash flows, and CASHIGLS ${ }_{\text {it }}$ is the differences between current HC and IA cash flows. 
Table 8: Results of pooled regression tests on the relative and incremental value relevance of $\mathrm{HC}$ and IA measures with respect to stock returns

\begin{tabular}{|c|c|c|c|c|c|}
\hline \multicolumn{4}{|c|}{$\begin{aligned} \text { RETURN }_{i t} & =\alpha_{0}+\alpha_{1} \text { EARNINGS }_{i t}+\alpha_{2} \text { YearDummies }+\varepsilon_{i t} \\
\text { RETURN }_{i t} & =\alpha_{0}+\alpha_{1} \text { EARNINGS }_{i t}+\alpha_{2} \text { EIGLS }_{i t}+\alpha_{3} \text { YearDummies }+\varepsilon_{i t}\end{aligned}$} & \multicolumn{2}{|c|}{$\begin{array}{l}(1) \\
(2)\end{array}$} \\
\hline \multicolumn{6}{|c|}{ Panel A: Yearly regressions } \\
\hline & 2001 & 2002 & 2003 & 2004 & 2005 \\
\hline \multicolumn{6}{|l|}{ Adjusted $\mathrm{R}^{2}$ : } \\
\hline $\mathrm{HC}$ accoun & .352 & .400 & .012 & .635 & .549 \\
\hline IA accounts & .027 & .033 & .036 & .524 & .420 \\
\hline Vuong tests & $2.2 * *$ & $2.8 * *$ & -.631 & $1.8^{*}$ & 1.2 \\
\hline
\end{tabular}

Panel B: Pooled regressions for entire sample period excluding 2003 observations

\begin{tabular}{|c|c|c|c|}
\hline Variables & $\begin{array}{c}\text { Model 1 } \\
\text { HC } \\
\end{array}$ & $\begin{array}{c}\text { Model 2 } \\
\text { IA } \\
\end{array}$ & $\begin{array}{c}\text { Model 3 } \\
\text { (Incremental) }\end{array}$ \\
\hline Intercept & $\begin{array}{l}0.384 \\
(0.04)\end{array}$ & $\begin{array}{l}2.620 \\
(0.22)\end{array}$ & $\begin{array}{l}1.018 \\
(0.10)\end{array}$ \\
\hline EARNINGS & $\begin{array}{c}6.981 \\
(13.44 * * *)\end{array}$ & $\begin{array}{c}7.616 \\
(8.64 * * *)\end{array}$ & $\begin{array}{c}8.421 \\
(11.77 * * *)\end{array}$ \\
\hline EIGLS & & & $\begin{array}{c}-2.572 \\
(-2.85 * * *)\end{array}$ \\
\hline Fixed time effects & Included & Included & Included \\
\hline Number of observations & 157 & 157 & 157 \\
\hline F-ratio & $53.17 * * *$ & $26.53 * * *$ & $47.76^{* * *}$ \\
\hline Adjusted $\mathrm{R}^{2}$ & 0.626 & 0.450 & 0.643 \\
\hline Vuong’s Z-statistics: HC vs IA Model & & $2.268 * *$ & \\
\hline HC vs Incremental Model & & & 0.318 \\
\hline IA vs Incremental Model & & & $2.372 * *$ \\
\hline \multicolumn{4}{|l|}{ Panel C: High inflation period $(2004-2005) \pm$} \\
\hline Intercept & $\begin{array}{l}-1.992 \\
(-0.26)\end{array}$ & $\begin{array}{l}3.725 \\
(0.42)\end{array}$ & $\begin{array}{l}-0.557 \\
(-0.07)\end{array}$ \\
\hline EARNINGS & $\begin{array}{c}7.000 \\
(9.66 * * *)\end{array}$ & $\begin{array}{c}9.682 \\
\left(7.45^{* * *}\right)\end{array}$ & $\begin{array}{c}9.185 \\
\left(8.31^{* * *}\right)\end{array}$ \\
\hline EIGLS & & & $\begin{array}{c}-3.907 \\
\left(-2.55^{* *}\right)\end{array}$ \\
\hline Fixed time effects & Included & Included & Included \\
\hline Number of observations & 76 & 76 & 76 \\
\hline F-ratio & $62.83 * * *$ & $40.29 * * *$ & $47.22 * * *$ \\
\hline Adjusted $\mathrm{R}^{2}$ & 0.625 & 0.512 & 0.649 \\
\hline Vuong’s Z-statistics: HC vs IA Model & & 1.186 & \\
\hline HC vs Incremental Model & & & 0.290 \\
\hline IA vs Incremental Model & & & 1.358 \\
\hline
\end{tabular}

*** Significant at 1\% level; ** significant at 5\% level; * significant at $10 \%$ level. $R E T U R N_{i t}$ denotes the share return of the firm over the 12-month period ending 4 months after the fiscal year-end (measured as the change in price plus dividend per share for the year and scaled by the beginning share price). EARNINGS is the reported basic earnings per share, calculated in accordance with IAS 33 - Earnings per share for HC and IA amounts, and EIGLS is the recognized inflation gains and losses in earnings (i.e., difference between HC and IA earnings). To mitigate the size or scale effects, we deflate EARNINGS and EIGLS by the share prices at the beginning of the returns annual window.

\pm We have not included the results for the low inflation period (2000-2002) in this table as there are no changes to those reported in Table 5, Panel A. 


\section{Appendix 1}

\section{An example of IA and HC financial statements presentation format}

\section{Group Income Statements}

\section{FOR THE YEARS ENDED $31 \mathrm{MARCH}$}

\begin{tabular}{|c|c|c|c|c|c|}
\hline & & \multicolumn{2}{|c|}{$\begin{array}{l}\text { INFLATION } \\
\text { ADJUSTED }\end{array}$} & \multicolumn{2}{|c|}{ HISTORICAL } \\
\hline & \multirow[t]{2}{*}{ Notes } & 2007 & 2006 & 2007 & 2006 \\
\hline & & \$m's & \$m's & \$m's & \$m's \\
\hline REVENUE & \multirow[t]{3}{*}{7} & 1183151 & 793202 & 375156 & 13483 \\
\hline Net gain on container deposit increase & & 192525 & 2975 & 66730 & 2 \\
\hline Fair Value Adjustment - Biological Assets & & 29383 & 8356 & 39260 & 363 \\
\hline NET OPERATING COSTS & \multirow[t]{2}{*}{8} & $\left(\begin{array}{lll}961 & 065\end{array}\right)$ & (701 087) & $(230120)$ & $\left(\begin{array}{ll}10 & 310\end{array}\right)$ \\
\hline OPERATING INCOME & & 443994 & 103446 & 251026 & 3538 \\
\hline Net financing income & \multirow[t]{4}{*}{9} & 32447 & 17174 & 15772 & 116 \\
\hline Monetary loss & & $\left(\begin{array}{lll}186 & 044\end{array}\right)$ & $(105063)$ & & \\
\hline \multirow[t]{2}{*}{ Equity accounted earnings } & & 3283 & $\left(\begin{array}{l}6 \\
141\end{array}\right)$ & 3147 & 80 \\
\hline & & 293680 & 9416 & 269945 & 3734 \\
\hline Taxation & \multirow[t]{2}{*}{10} & $(95803)$ & 2840 & $(80539)$ & $(960)$ \\
\hline INCOME AFTER TAXATION & & 197877 & 12256 & 189406 & 2774 \\
\hline \multicolumn{6}{|l|}{ Attributable to: } \\
\hline Equity holders of the parent company & & 182607 & 8741 & 165665 & 2383 \\
\hline \multirow[t]{2}{*}{ Minority interest } & & 15270 & 3515 & 23741 & 391 \\
\hline & & 197877 & 12256 & 189406 & 2774 \\
\hline \multicolumn{6}{|l|}{ EARNINGS PER SHARE (DOLLARS) } \\
\hline - attributable and headline earnings basis & 4.6 & 178,27 & 8,69 & 161,73 & 2,37 \\
\hline - cash equivalent earnings basis & 4.7 & & & 132,33 & 2,09 \\
\hline DIVIDENDS PER SHARE (DOLLARS) & 11 & 22,15 & 21,15 & 14,0 & 0,5 \\
\hline
\end{tabular}




\section{Appendix 1 - Continued}

Notes to the Financial Statements

\begin{tabular}{|c|c|c|c|c|c|}
\hline & & \multicolumn{2}{|c|}{$\begin{array}{l}\text { INFLATION } \\
\text { ADJUSTED }\end{array}$} & \multicolumn{2}{|c|}{ HISTORICAL } \\
\hline & & 2007 & 2006 & $\begin{array}{r}2007 \\
\$ m\end{array}$ & $\begin{array}{l}2006 \\
\$ \text { m'c }\end{array}$ \\
\hline & & \$m's & \$m's & & \$m's \\
\hline \multirow[t]{3}{*}{8.} & OPERATING INCOME & & & & \\
\hline & Operating income is arrived at after & & & & \\
\hline & charging/(crediting):- & & & & \\
\hline \multirow[t]{12}{*}{8.1} & NET OPERATING COSTS & & & & \\
\hline & Sundry operating income & $(21442)$ & $(10419)$ & $(1916)$ & $(379)$ \\
\hline & Changes in inventories of finished & & & & \\
\hline & goods and work in progress & (169 216) & (11 621) & (106 167) & 207 \\
\hline & Raw materials and consumables used & 527050 & 276669 & 157788 & 3257 \\
\hline & Depreciation expense (note 8.2 ) & 28340 & 29560 & 321 & 41 \\
\hline & Staff costs & 131914 & 104208 & 50925 & 1857 \\
\hline & Excise, levies and value added tax & 234798 & 178477 & 78329 & 3073 \\
\hline & Loss/(Profit) on disposal of subsidiary & 1260 & - & $(507)$ & - \\
\hline & Share option expenses & 15176 & 5841 & 2527 & 49 \\
\hline & Other operating expenses & 213185 & 128372 & 48820 & 2205 \\
\hline & & 961065 & 701087 & 230120 & 10310 \\
\hline \multirow[t]{5}{*}{8.2} & DEPRECIATION OF PROPERTY, & & & & \\
\hline & PLANT AND EQUIPMENT & & & & \\
\hline & Buildings & 2179 & 4527 & 5 & 1 \\
\hline & Plant, equipment and vehicles & 26161 & 25033 & 316 & 40 \\
\hline & & 28340 & 29560 & 321 & 41 \\
\hline \multirow[t]{7}{*}{8.3} & AUDITORS' REMUNERATION & & & & \\
\hline & Current year audit fees and expenses & 9490 & 1792 & 2997 & 30 \\
\hline & Prior year under/(over) under provision & 95 & $(20)$ & 31 & - \\
\hline & & 9585 & 1772 & 3028 & 30 \\
\hline & Included in current year Group audit & & & & \\
\hline & fees are fees for the company of & & & & \\
\hline & $\$ 37$ million (2006 - $\$ 1,2$ million). & & & & \\
\hline \multirow[t]{3}{*}{8.4} & NET LEASING EXPENSE & & & & \\
\hline & Lease payments: & & & & \\
\hline & - Minimum lease payments & 8735 & 4983 & 2532 & 85 \\
\hline
\end{tabular}

Source: Delta Corporation (Zimbabwe) Ltd. Annual Report (2007: 27 and 44). [www.delta.co.zw] 